NBER WORKING PAPER SERIES

\title{
ON THE ORIGINS OF THE IDEA OF ENDING POVERTY
}

\author{
Martin Ravallion \\ Working Paper 27808 \\ http://www.nber.org/papers/w27808 \\ NATIONAL BUREAU OF ECONOMIC RESEARCH \\ 1050 Massachusetts Avenue \\ Cambridge, MA 02138 \\ September 2020
}

For helpful comments, the author thanks Tim Besley, Francisco Ferreira, Martin Gutmann, David Hulme, Michael Lokshin, Giovanni Vecchi, Dominique van de Walle and Nicolas van de Walle. The views expressed herein are those of the author and do not necessarily reflect the views of the National Bureau of Economic Research.

NBER working papers are circulated for discussion and comment purposes. They have not been peer-reviewed or been subject to the review by the NBER Board of Directors that accompanies official NBER publications.

(C) 2020 by Martin Ravallion. All rights reserved. Short sections of text, not to exceed two paragraphs, may be quoted without explicit permission provided that full credit, including (C) notice, is given to the source. 
On the Origins of the Idea of Ending Poverty

Martin Ravallion

NBER Working Paper No. 27808

September 2020

JEL No. B00,I30

\begin{abstract}
$\underline{\text { ABSTRACT }}$
The late 18th century saw the intellectual germ of the idea of "ending poverty," but the idea did not get far in economics or policy making until much more recently. Over the 19th century, poverty rates fell substantially in Western Europe and North America, and we started to see mainstream advocates of ending chronic poverty, and policies for doing so. There was an explosion of interest in the idea from around 1960, with policy responses in many countries, including America. In the post-Colonial period, the newly independent states were keen to see an end to poverty. From the 1990s, development agencies began to identify this as their overarching objective. The U.N.'s first Millennium Development Goal (MDG1) of halving the 1990 poverty rate by 2015 was achieved ahead of time. The U.N.'s Sustainable Development Goals came to include ending extreme poverty by 2030. This is more ambitious than MDG1, and more politically challenging. Economic growth in poor countries is likely to remain important, but the policy emphasis has shifted to redistributive interventions, though these will require a deeper reach to the poorest if we are to see the end of poverty, judged by any chosen poverty line.
\end{abstract}

\author{
Martin Ravallion \\ Department of Economics \\ Georgetown University \\ ICC 580 \\ Washington, DC 20057 \\ and NBER \\ mr1185@georgetown.edu
}


"History repeats itself, says an ancient proverb, and historians repeat each other." (Mark Blaug 1963, p.152)

\section{Introduction}

This paper provides a short history of the idea of ending poverty. The focus is on economic thought and its bearing on policy, though going back to times when disciplinary boundaries were more blurred than today. The quote above (from a prominent economist at the time) is obvious hyperbole and does not only apply to historians. But it contains some truth. The history of thought on poverty has long periods of agreement among historians and others, then long periods of agreement on virtually the opposite view.

There are times and places when announcing a goal for ending poverty is clearly little more than a symbol of good intentions. It tells poor citizens, and those who care about them, that the government (or international agency) purports to be on their side, even if nothing much is done to ease poverty. This can be called a "symbolic goal."

At times there have also been more substantive aims. Advocates against poverty have variously seen it as: the most morally objectionable aspect of inequality, stemming mainly from economic and political forces rather than bad choices by poor people; a key material constraint on human freedom and social inclusion; a risk of deprivation, whether currently poor or not; and a cost to other valued goals, including economic efficiency, human development and environmental sustainability. The actions that might be motivated in response range from specific policies to efforts to help poor people organize collectively for things that matter to them. Thus, goal setting is seen as an incentive mechanism for attaining better outcomes. We can call this the "motivating goal."

Either way, it must first be agreed collectively that less poverty is a good thing. As we will see, history suggests that this is a modern idea, little evident in pre-modern times. One might suggest that the underlying preferences of people changed over time, so as to care more about poverty. That would be an easy explanation, but surely hard to justify. This paper will focus more on explanations that do not assume that preferences changed. It may have been agreed that less poverty is desirable per se (for many reasons, both intrinsic and instrumental), but significant trade-offs were expected against other valued goals. The focus then switches from preferences to the constraints that determine choices given those tradeoffs. Nor is it sufficient that many 
individuals agree that less poverty is desirable, and that a policy response is required. Those individuals also need to be able to organize themselves collectively to form a sufficiently influential coalition. That can be challenging.

The balance of factors influencing the motivating goal is likely to change with economic development, and vary from one place to another. Politically, the perceived benefits depend on the weight given to poor people, which depends in turn on their voting power and their capacity to organize. The cost of ending poverty through redistribution depends (in part) on how much poverty there is, relative to the resources thought to be available. It can be no surprise that calls for ending poverty have been heard more often when a society's total resources make it more feasible to do so. In The Abolition of Poverty, the economist Jacob Hollander (1914, p.18) put it nicely: "It is because the whole loaf is large enough to satisfy the hunger of all who must be fed that individual want is intolerable." Similarly, economic growth is more likely to be emphasized as the route out of poverty when there is seen to be a lot of poverty - that the loaf is too small.

Advocates of ending poverty must commit to at least a rough idea of what that means. The most common definition is that no household has an income per person (or per equivalent single adult) below a poverty line. That is the definition used in this paper, but some limitations should be acknowledged. Sample survey data are invariably used for measuring poverty, though some poor people may well be underrepresented, such as the homeless. The survey-based measures are rarely ideal in other respects. Shocks and measurement errors entail that transient spells of measured poverty, based on surveys, remain even if everyone has their normal standard of living - consumption averaged over a reasonable time period - above the poverty line. Taken literally, measured poverty may never be zero.

Standard household surveys have another problem. Consumption and some income sources are mostly only measured at the household level. Finding that all households have a per capita consumption above the line does not mean that poverty has ended in the sense that no individual is poor. There is evidence that poor people are quite often found in "non-poor" households. ${ }^{2}$ Poverty may well remain even when the standard criteria for "ending poverty" are met.

One might further object that some people have chosen to be poor, and whatever is done they will make that choice. This is possible but seems unlikely to apply to many people. In the

\footnotetext{
${ }^{2}$ See, for example, Haddad and Kanbur (1990), Brown et al. (2019) and De Vreyer and Lambert (2020).
} 
history of thought on poverty one often finds a distinction between the "deserving" and "undeserving" poor, the latter being blamed for their "bad behaviors," such as not working hard enough. ${ }^{3}$ This does not appear to have been based on any credible evidence that those deemed to be undeserving had freely chosen to be poor. (Observed behaviors among poor people are often interpreted as causes of their poverty when they could well be its effects.) More plausibly, this was (and still is) a convenient moralistic rationale for prioritizing limited relief among large numbers of poor people. Also, the emphasis given to the idea that the able-bodied poor are "undeserving" echoed a desire among the emerging capitalist class to maintain aggregate labor supply, and so keep wages low. At times, such distinctions served other purposes, including as a camouflage for racial or ethnic discrimination, built on ill-founded stereotypes. Work and other incentive effects can certainly be relevant to good policy making, but it is hard to justify any constraint that withholds all help for the able-bodied poor.

The expected cost of ending poverty also depends on the desired minimum income and the targeted time to reach zero. These are not of course exogenous, but rather parameters to be chosen. If the chosen date is too soon, or the line is set too high, such that there is a hefty bill expected for ending poverty, it will be harder to form a political consensus for direct action. The goal will have weaker motivational power. That will also be true if the line is set too low, or the goal is too far into the future; then it may be irrelevant, as it would not call for any extra effort today. A target date more than (say) 20 years away may matter little to the efforts of politicians, administrators and civil society groups. For a motivating goal to succeed in a specific context, the desired minimum income, and date to reach it, must be set recognizing that the goal cannot be seen as too hard, or too easy. ${ }^{4}$

The paper begins by looking briefly at how poverty figured in ancient thought. Section 3 focuses on the period from the mid- $18^{\text {th }}$ up to the late- $19^{\text {th }}$ century, including a 20 year period at the end of the $18^{\text {th }}$ century which can claim to have given birth to the idea of ending poverty, though then it was nothing much more than an idea, and not widely held. Section 4 focuses on the change in mainstream thinking around the late $19^{\text {th }}$ century, and how the policy focus on

\footnotetext{
${ }^{3}$ The distinction is common though the labelling has varied. For example, Anderson (1978, p.69) uses the term "needy-only" for (essentially) the deserving poor.

${ }^{4}$ This is an instance of a more general property of endogenous "aspirations," as discussed in Genicot and Ray (2020). When an aspiration (such as for one's children) is considered to be attainable it can have a positive incentive effect; on the other hand, if the aspiration is too far beyond reach it can be useless or even detrimental.
} 
poverty evolved subsequently. Section 5 looks at the explosion of interest in ending poverty that emerged in the 1960s, while Section 6 turns to the goals for reducing poverty that arose in the 1990s, leading up to the first of the U.N.'s Sustainable Development Goals (SDG1) aiming to “end poverty" by 2030. Section 7 concludes.

\section{Ancient antecedents}

Poverty was taken for granted in pre-modern times, but it was not ignored. Avoiding mass starvation has long been a political objective. The emphasis was mostly on protecting people from shocks; in other words, the concerns were mainly about transient poverty. (By contrast, chronic poverty can exist even when consumption levels are perfectly stable over time.) A large part of the motivation was maintaining the social order. Protection from covariate risks was an undeniable priority, as such shocks could generate mass protests that threaten the social order (Piven and Cloward 1979).

This spanned the many regimes of the ancient world. To illustrate, let us consider three intellectuals from the time. The first is the Greek philosopher Aristotle, writing around 350 BCE. Aristotle had a concept of "distributive justice," but it emphasized meritocracy — the assignment of rewards according to merit (Fleischacker 2004). Only the most skilled applicant should be chosen for public office. Aristotle's concept of justice was clearly appealing to a free and aspiring middle class, and gave some hope to poor but free people. But the idea posed little challenge to more fundamental inequalities in society. Ideas of "equal opportunity" and the rights of all to "liberty" were known to Aristotle, but were at best secondary to the benefits of a "natural order" in which subordination, even in the form of slavery, was accepted in elite circles. Aristotle's idea of justice appears to have been consistent with prevailing practice. The government of democratic Athens made hand-outs in various forms, but maintaining the civic order was their main aim, not ending poverty or attenuating inequality (Taylor 2017, Chapter 5). Poor people may well receive some support from the state but not because they are poor.

On the other side of the globe, in China around $500 \mathrm{BCE}$, Confucius identified poverty as one of the "six calamities" that good government should help avoid. ${ }^{5}$ However, chronic poverty associated with wealth inequality was not a prominent policy concern. More worrying was any

\footnotetext{
5 The other five calamities were: early death, sickness, misery, a repulsive appearance and weakness. There were also five blessings: ample means, long life, health, virtuous character, and an agreeable personal appearance.
} 
threat to the harmonious social order. For Confucius, "poverty" would not threaten as long as that order was maintained: "When the people keep their respective places, there will be no poverty; when harmony prevails, there will be no scarcity of people; when there is repose, there will be no rebellions" (Confucius, quoted in Dawson, 1915. p.186).

The third example is Kautilya (also known as Chanakya), writing around 300 BCE in ancient India. Kautilya could well have been the first economist. The title of his (undated) major work can be translated as The Science of Material Gain, or The Science of Polity. The span of his policy advice included policies for addressing the social costs of shocks by providing employment on government-sponsored public works schemes - an early form of Keynesian stabilization - though he also recognized transfers as an option. Again, the motivation was to assure the stability of the regime.

From the time of these ancient antecedents until the modern era, the perceived role of governments in alleviating poverty was largely confined to dealing with transient, politically destabilizing sources, such as famines. Private charity and religious institutions were more important historically, especially in providing help for the disabled or infirm. Many theologies have extolled charity as a personal virtue, founded on empathy for the plight of others less fortunate. Local religious organizations have long been charged with this beneficence role.

The stability of the regime would remain an influence on policy making over the subsequent millennia. However, a new set of motivations emerged in the late $18^{\text {th }}$ century, pointing to a role for the state.

\section{The First Poverty Enlightenment and its aftermath}

There was a great deal of poverty in the world around 1800. Bourguignon and Morrisson (2002) estimate that $80 \%$ of the World's population in 1820 (the earliest year in their series) lived in poverty, as judged by the World Bank's frugal international line. Ravallion (2016, Chapter 1) provides a breakdown of that $80 \%$ figure by regions of the world. ${ }^{6}$ The numbers suggest that around 1820, roughly half the population of Europe lived in what we would consider today as extreme poverty, namely poverty as judged by standards found among the poorest countries in modern times; the poverty rate was probably somewhat lower in the UK and US

\footnotetext{
${ }^{6}$ The data were poor back then and these numbers must be considered only broadly indicative at best.
} 
than Western Europe. ${ }^{7}$ These included employed poor, in addition to the large numbers of unemployed workers and beggars that had been filling the new slums of industrializing cities (Engels 1845; Jütte 1994). Agrarian changes - such as Britain's (state-enforced) enclosures of open fields - had released workers from agriculture, though not all of them could be absorbed quickly into the new urban-industrial economy.

Mainstream thinking had for some time regarded chronic poverty as a more-or-less inevitable by-product of the economic transition from feudalism to capitalism, which (once slavery had been outlawed) was seen to require low wages rates. For some 300 years prior to 1800 , the dominant school of economic thought - what came to be known as "mercantilism"saw poverty associated with low wages as an essential precondition for economic development. Ending poverty would have come at an unthinkable cost to the wealth and power of the regime. Hunger encouraged work, and lack of it did the opposite. This acceptance of poverty was also found in America; "During the first two centuries of the country's development Americans took it for granted that the majority of men would always be poor" (Bremner 1956, p.3).

Adam Smith's, The Wealth of Nations, rejected the mercantilist view that a country's economic welfare should be judged by the balance of trade (value of exports less imports). $\mathrm{He}$ sought a broader measure based on the population's command over commodities. Smith opened the way to seeing progress against poverty as a goal for development, rather than a threat to it "... no society can surely be flourishing and happy, of which the far greater part of the members are poor and miserable." (Smith, 1776, Book 1, Ch.8). Similarly, he saw higher real wages as a good thing, also in contrast to longstanding mercantilist views. (Nor did Smith accept that the rich all deserved to be rich; inequality could be against the national interest when it stemmed from monopolistic powers.) There is little to suggest that Smith seriously thought that poverty could be eliminated, but he did think that less of it was a good thing. Nor did he appear to see a tradeoff between reducing poverty and promoting economic growth. ${ }^{8}$

Smith exemplifies a marked change in elite thinking relevant to ending poverty in the last few decades of the $18^{\text {th }}$ century that can be called the First Poverty Enlightenment (Ravallion,

\footnotetext{
${ }^{7}$ See Ravallion (2016, Figure 1.1). What was considered "poverty" at the time may well have assumed a more generous standard than this. Jeremy Bentham (1843), writing about England near the end of the $18^{\text {th }}$ century, reckoned that $95 \%$ of the population was "poor." But he provides no evidence. Gazeley and Verdon (2014) estimate a household poverty rate of $82 \%$ in rural England around 1800 .

${ }^{8}$ For further discussion of this aspect of Smith's thinking see Rothschild (1995).
} 
2015). (It should be noted that this is based on the written record, which need not have reflected at all well how poor people thought. Illiteracy was common, especially among the poor. ${ }^{9}$ ) A more sympathetic attitude to poor people emerged in texts from around the mid- $18^{\text {th }}$ century, notably with greater recognition that many poor people did nothing to warrant their poverty (Coats 1992, Chapter 5). The distinction between "deserving" and "undeserving" poor is objectionable to many minds today, but in the late $18^{\text {th }}$ century it was progressive to recognize that at least some poor people deserved help as they were blameless for their misfortune.

An intellectual starting point for this change in thinking had been provided by the arguments of Jean-Jacques Rousseau and Nicolas de Condorcet (the Marquis of Condorcet) that poverty was in no small measure man-made rather than a natural order of things. Immanuel Kant (1785) argued for a more respectful attitude toward poor people, implying that the state rather than private charity should take responsibility for promoting people from poverty (Fleischacker 2004). The period also saw the first efforts at defining a poverty line, namely those of David Davies (1776) and Frederick Eden (1797), writing about living standards in rural England (Gazeley and Verdon 2014). ${ }^{10}$ Stedman Jones (2005) identifies this as the time when the idea of ending poverty emerged.

Policy ideas to reduce poverty started to be more prominent. An interesting example is Thomas Paine's advocacy of a uniform dividend paid for by a tax on land. It is not clear that Paine (1797) had a vision of eliminating poverty — he appears to have been more concerned with recognizing societal rights to natural resources. ${ }^{11}$ Whether his uniform dividend would eliminate poverty depends on many things, including the distribution of land ownership, and whether the attainable income gain net of land taxes (allowing for effects on other wages and prices) allowed everyone to escape poverty. But Paine's idea did admit the possibility of ending poverty. It was the germ of the idea of what is called today a universal basic income (UBI).

Around the same time, Jeremy Bentham was rejecting as ad hoc the many rights-based rationales for policy, preferring instead to base social choices on their consequences for

\footnotetext{
${ }^{9}$ For example, about half the adult population of England was illiterate around 1800 (Lloyd 2007). ("Literate" was defined by the minimal criterion of being able to sign one's name.) Social novels (by authors such as Charles Dickens and Elizabeth Gaskell) have provided useful clues as to how poor people thought in the mid- $19^{\text {th }}$ century. ${ }^{10}$ Davies (1776, p.33) did not use the term "poverty line" (which first appeared around 1900 in the context of Charles Booth's studies), but calculated a sum of money for working class families "to provide for themselves all necessities and live in tolerable comfort, independent of parochial assistance."

${ }^{11}$ Paine's (1791) Rights of Man also outlined how fiscal efforts to reduce poverty might be improved, though there is no mention of eliminating poverty as the goal.
} 
individual utilities. As subsequently interpreted (including by his student, John Stuart Mill), Bentham's "greatest happiness principle" meant that, when some people gained but some lost, the social choice should maximize the sum of their utilities. Benthamite utilitarianism penalized income inequality under the (intuitively appealing) assumption of diminishing marginal utility of income (as developed more rigorously with the marginalist revolution in economics later in the $19^{\text {th }}$ century). This provided a qualified consequentialist case against income inequality between otherwise identical people; "qualified" because the case is weakened when people differ in their marginal utility from a given income and/or when redistribution entails a loss in mean income.

Benthamite utilitarianism did not provide a case for ending poverty. In principle, there could be a gain to the richest person that justified a loss to the poorest. Bentham did, however, advocate policies that could help reduce poverty. An example is the idea (found in Bentham's writings around 1800 and elaborated by Mill) of an exemption from income taxation for all incomes below a critical "subsistence" level; above that level, the tax would be proportional to income, but (given the exemption) the overall schedule would be progressive (higher average tax rates at higher incomes). ${ }^{12}$ It would be roughly another 100 years before progressive income taxes would become a reality in most countries, but this was the germ of that idea.

Antipoverty policies existed in Europe and North America around this time, such as under various "Poor Laws." The daily inconvenience of paupers and beggars in the major cities prompted "poor relief," which was only intended for the "deserving poor," to protect them from transient distress that prevented work or to help them cope with (physical or mental) disability. The policies did not aim to end chronic poverty. Indeed, the commonly applied distinction between deserving and undeserving poor made it clear that poverty among low-wage workers was not something for policy makers to worry about. However, it was not always clear in practice how the "deserving poor" could be distinguished from the "undeserving poor." A common policy instrument to help separate the two was the publicly-financed workhouse. The idea was that welfare recipients would need to agree accepting all relief in kind, as food and lodging in the workhouse, although the work itself was not the point. ${ }^{13}$ The real aim was to assure that working for a wage, no matter how low, was preferable to the workhouse. Work

\footnotetext{
${ }^{12}$ The rationale was (in part at least) that poor people were already burdened by regressive indirect taxes. See the discussion in Scheve and Stasavage (2016, Chapter 2).

${ }^{13}$ William Petty (1662) argued that it would be better to employ idle poor people in some entirely wasteful wayPetty's example was a project moving the stones of Stonehenge to Tower Hill - than to leave them idle.
} 
requirements continue to this day as a means of dissuading the supposedly "undeserving poor," as well as the non-poor, from seeking relief.

Some countries invested more in poor relief than others. England's Poor Laws are a famous example, about which much has been written. Each parish was obliged to deal with its poverty problem using state-contingent transfers intended for those deemed unable to work, such as elderly widows or the disabled, financed by local property taxes. (Naturally, richer parishes tended to be more generous, generating horizontal inequity.) Solar (1995) argues that England's Poor Laws (going back to around 1600) were important to the country's long-term social stability, including in the late $18^{\text {th }}$ century when there was much concern about the possibility of the French Revolution spilling across the English Channel. Poor relief had taken on new roles in the $18^{\text {th }}$ century, including in addressing seasonal unemployment in agriculture (Boyer 1990).

By the late $18^{\text {th }}$ century, in much of England, the Poor Laws had evolved into the "Speenhamland System." There were multiple versions, but the main idea was to provide an income guarantee, indexed to the price of bread and adjusted for household size. Like Paine's proposal, this would have assured a minimum income if financed from those living well above that income. However, in contrast to Paine's proposal, it provided a targeted supplement to wages, to assure that the desired bread purchasing power was reached. If you earned less than that, then you got the required top up; if you earned more you got nothing.

This distinction between a UBI and targeted transfers to assure a minimum income would prove to be a persistent source of confusion in the history of thought. In terms of incentives, the difference is huge: assuming the scheme is paid for by the non-poor, the means-tested transfers to reach the minimum income would have a much greater work disincentive, since (on paper at least) one's final income was disconnected from how much or how hard one worked. This is the main reason that the two most respected economists of the time, Thomas Malthus and David Ricardo, came to be staunch critics of the Speenhamland scheme, which influenced the very negative assessment of the scheme by a Royal Commission. It was argued by the child benefits would encourage higher fertility, thus further impoverishing recipient families. With little or no incentive to work, agricultural output would fall, and the emerging industrial capitalism would have too few workers (Polanyi 1957). The policy was also seen as counter-productive for workers. It was claimed by Friedrich Engels (1845), among others, that employers would simply cut workers' wages, leaving the Speenhamland scales to make up the difference. 
These Speenhamland critiques were repeated often over the subsequent 200 years. ${ }^{14}$ Yet careful analyses of the evidence available at the time provide only limited support. The incentive effects on labor supply do not appear to have been as large as the critics imagined. Based on data available to the Royal Commission (but not used), Blaug (1963) did not find that the Speenhamland scheme depressed wages or reduced agricultural productivity. ${ }^{15}$ In practice the scheme appears to have provided limited unemployment insurance, and avoided payments to able-bodied workers when work was available (Boyer 1990; Block and Somers 2003). There is supportive evidence for the claims that the scheme encouraged higher fertility (Boyer 1990).

The critics won and the scheme was abandoned under reforms in 1834, in the wake of the Royal Commission's Report. The reforms entailed much greater use of workhouses, with the idea that these would be so unpleasant that only the truly needy would accept relief, and that they would readily leave when better opportunities arose. Following Polanyi (1957), Besley et al. (2004) argue that the 1834 reforms emerged out of the structural transformation from a feudal agrarian economy to an urban-based industrial-capitalist economy. This had important implications for the information available on who is poor and why, requiring stronger incentives to assure that only the "deserving poor" turned for help from the Poor Laws. That is a plausible argument, though not much less so 50 years earlier when no such reforms were being considered. The 1834 reforms must also be put in the context of the political economy of the time. The fear that the French Revolution would cross the English Channel had faded and Napoleon Bonaparte had been defeated, though this left many unemployed ex-soldiers turning to the Poor Laws. Political pressure for spending cuts had been mounting from the rural landholders, who paid the taxes to finance the Poor Laws. The reforms using workhouses achieved a large cut in spending, almost certainly by denying benefits to many poor families (Lindert 2004). Similar reforms were undertaken in America, and probably with similar effects (Katz 1996).

Economics was becoming as a respected field of study around this time, but it did not provide any reason to imagine that poverty might be eliminated. A recurrent message was to limit state interventions. Nor was economic development seen as a route out of poverty. Where slavery had been abolished, "the poor" were essentially the destitute and the working class, and the real wage rate for unskilled labor was the most important economic variable determining the

\footnotetext{
${ }^{14}$ See, for example, Polanyi (1957, Chapter 7), Anderson (1978) and Himmelfarb (1984).

${ }^{15}$ Also see Glaper (1970), Block and Somers (2003) and Clark and Page (2019).
} 
welfare of poor people. (There was still wage inequality among workers, as described by Engels 1845.) Yes, poor people would gain from higher wages, but this was not thought to be sustainable. Ricardo's idea of diminishing returns suggested strict limits to output growth at given technologies. On top of this, the fertility response to any increase in the wage rate (and hence reduction in the poverty rate) would soon increase labor supply and bring the wage rate back down. Malthus is famous for this view - in what came to be known as the Malthusian Trap - but it was widely held in the $19^{\text {th }}$ century (Sandmo 2015). This stood in marked contrast to the prior views of Condorcet, Smith and others that less poverty would result in lower fertility.

Nor did the new Marxian school of economics offer any hope of ending poverty under capitalism. Echoing the Enlightenment thinkers of the $18^{\text {th }}$ century, Karl Marx rejected any suggestion that poverty is some natural state. He also rejected the classical economists' views on how induced population growth would keep the wage rate at a fixed "subsistence" level. ${ }^{16}$ Nor did he assume that the wage rate would automatically fall to clear the market; full employment could not be attained even at the "subsistence" level of wages, although it was never very clear what that meant. ${ }^{17}$ For Marx, it was the presence of surplus labor (the "reserve army of the unemployed" in Marx 1867, Chapter 25) that would hold down wages, and assure that poverty persisted, at least in the absence of strong trade unions.

The $19^{\text {th }}$ century did see steps toward more promotional policies, including the emergence (albeit slowly, amidst much debate) of mass public schooling, as Condorcet had advocated around 1790, but with little real impact at the time. However, mass chronic poverty appears to have still been accepted as more-or-less inevitable through much of the $19^{\text {th }}$ century. This is consistent with the fact that one finds no references in digitized texts from that period to the concepts, "ending poverty," "eliminating poverty," or "eradicating poverty."18

While the First Poverty Enlightenment brought the idea that less poverty is a good thing, it did not see much further development, or even much encouragement, for the bulk of the $19^{\text {th }}$ century. The seed of the idea of ending poverty would take 100 years or more to bear fruit.

\footnotetext{
16 See Baumol (1983) on Marx’s theory of wage determination.

17 This claim is common in writings on the Industrial Revolution (IR) in Britain. Yet wages appear to have been quite high there (relative to Western Europe), which is one likely reason why the IR started in Britain (Allen 2009).

18 This can be verified by entering these terms in the Google Ngram Viewer.
} 


\section{4. "A serious flaw in our economic organization"}

The $19^{\text {th }}$ century saw progress against global poverty—about a $15 \%$ point drop in the poverty rate over the course of the century (Bourguignon and Morrison 2002). More progress was seen in Western Europe and North America, where the poverty rate fell from around 50-60\% in 1820 to somewhere around $20 \%$ near the end of the $19^{\text {th }}$ century (Ravallion, 2016, Figure 1.1). A likely explanatory factor was the rise in real wages in the newly industrializing countries. The Industrial Revolution in Britain had initially seen only modest growth in real wages, but this started to change in the $19^{\text {th }}$ century, and by 1900 the real wage rate was four times its level in 1800 (Crafts and Mills 1998). Nonetheless, over the bulk of the $19^{\text {th }}$ century, overall income inequality tended to rise in the industrializing countries (Milanovic 2016).

By the late $19^{\text {th }}$ century we started to see an emerging view in mainstream circles that poverty should and could be eliminated. Alfred Marshall motivated his famous textbook, Principles of Economics, with a discussion of the "evil" of poverty, and expressing "the hope that poverty and ignorance may gradually be extinguished" (Marshall 1890, p.3). This was in part an ethical objection to poverty, also an instrumental economic case. In Marshall's (1890, p.594) view, "The inequalities of wealth ... are a serious flaw in our economic organization." In a radical departure from mainstream thinking, Marshall (1890, p.191) identified poverty as a source of underinvestment in the "human faculties" of children. By constraining the production of this important form of capital, poverty could retard economic growth. Marshall did not say much about specific antipoverty or redistributive policies, but his concern was apparent.

The historian Robert Webb argues that, in England, it was this period of the late $19^{\text {th }}$ century when it came to be widely recognized that poverty "could and must be eliminated" (Webb 1974, p.384). Something similar was happening elsewhere in Europe and North America, with new optimism about the scope for human progress, and poverty reduction in particular, around the turn of the century and in the first 15 years of the new century. ${ }^{19}$ This new recognition of the case for ending poverty marked the beginning of a period of progressive reforms in much of the (newly) "rich world," including early forms of social insurance, minimum wage laws and progressive income taxes. This started in Western Europe, but then spread to North America and

\footnotetext{
${ }^{19}$ See, for example, the discussion in Vecchi (2017, Chapter 9) with reference to Italy and Bremner (1956, Chapter 8) with reference to the U.S.
} 
Japan. These policies undoubtedly contributed to the decline in income inequality seen in the rich world in the early decades of $20^{\text {th }}$ century, though other factors were also in play, such as the destruction of capital assets during World War 1 (WW1) (Piketty and Saez 2014).

One can point to possible reasons for this change in thinking about poverty that started in the late $19^{\text {th }}$ century. Less poverty meant that direct interventions against poverty were seen to be more feasible politically, in large part because less redistribution was required than when poverty was pervasive. Universal suffrage was not yet achieved (though universal male suffrage had been attained in some countries). However, there had been a large rise in literacy rates over the $19^{\text {th }}$ century, which helped in spreading knowledge and facilitating collective action toward goals such as reducing poverty (and universal suffrage).

Rising inequality in the $19^{\text {th }}$ century and the lack of obvious progress in softening the social impacts of capitalism helped encourage the formation of socialist organizations and labor movements in Europe and North America. Unionization had also been spreading to relatively unskilled workers (having initially been confined to skilled workers). All this encouraged pro-poor policy reforms, albeit with much debate and long lags. Famously Chancellor Bismarck in Germany in the 1880s introduced comprehensive social insurance in an attempt to "lure the workers away from the socialists" (Landauer 1959, p.276). In the period up to WW1, the socialist movement gained strength internationally, fusing over time with much of the labor movement.

New knowledge also played a role, both in quantifying the extent of poverty and in understanding its causes. While well-healed citizens had been learning at times from newspapers and art about the living conditions of those less fortunate, the science was weak, or absent. This started to change with pioneering empirical studies by Charles Booth and Seebohm Rowntree, who documented the living conditions of England's poor (in London and York respectively) in the late 19th century. These were careful observational studies, though certainly not rigorous sample surveys (the tools for which were yet to be developed). Both Booth and Rowntree were striving to respond in a scientific way to casual claims made by social critics from the left about the extent of poverty. Booth - a politically conservative ship owner-was reacting (in disbelief) to the claim by a society of Marxists that one quarter of Londoners were poor. After 17 years of study, employing hundreds of staff, he concluded it was $30 \%$, though he also taught Londoners a lot about poverty in their city. 
In the process, Booth founded the modern social survey movement (Bateman 2001). This took off from the late $19^{\text {th }}$ century, encouraged by (among others) Richard T. Ely, an economist who studied poverty and was a founder of the American Economic Association. (A co-founder was Katherine Coman, who had a similar interest in poverty.) Booth's study motivated similar studies of poverty in the U.S., by W.E.B. Du Bois and Robert Hunter, and elsewhere, including India (Thorner 1967). The old view of poverty as "pauperism" had emphasized charity and dependency, while the new view, drawing on the new data, emphasized multiple economic and social factors leading to both chronic and transient poverty (Bremner 1956, Chapter 8).

By the early $20^{\text {th }}$ century it was becoming accepted that social progress could be assessed, in part at least, by tracking how many people lived below some point in the distribution of income. The point chosen could be called a "poverty line," but to many economists and statisticians that was not the crucial aspect. As Arthur Bowley (1915, p.213) put it: "There is perhaps, no better test of the progress of a nation than that which shows what proportion are in poverty; and for watching the progress the exact standard selected as critical is not of great importance, if it is kept rigidly unchanged from time to time." In America, Allyn Young (1917) also advocated focusing measurement attention on the distribution of the levels of income or wealth, rather than the new measures of inequality that were emerging, including the Gini index.

The idea of ending poverty developed unevenly over the $20^{\text {th }}$ century. In America in some periods - the 1920s and the immediate post-World War 2 (WW2) period-there appears to have been a popular delusion that poverty had in fact ended, reflecting a "..widespread belief in mass prosperity" (Trattner 1999, p.308). The poverty focus gained political momentum in the wake of the Great Depression. In his second inaugural address, U.S. President Franklin D. Roosevelt (1937) famously said that: "The test of our progress is not whether we add more to the abundance of those who have much; it is whether we provide enough for those who have too little." Roosevelt's new social programs - bundled under the label "New Deal"-included the Social Security Act, which introduced federal pensions for the elderly, transfers for families with dependent children, and unemployment benefits. The prior introduction of the federal income tax (under President Taft) provided a progressive method of financing.

The Great Depression illustrates how a large covariate shock can foster longer-term social progress, although other factors have to be in place already, including the policy ideas. Political constraints on social policy still loomed large; for example, the New Deal policies 
largely avoided the longstanding issues of racial inequality in America, out of respect for the Southern Democrats who were so important to congressional power at the time.

The Depression also challenged the view that inequality was good for growth. Poverty created by mass unemployment (and plainly not caused by the bad behaviors of workers) was a motivation for the Keynesian Revolution in economics. Keynes's (1936) argument that aggregate effective demand - consumption rather than savings - is the key constraint on attaining full employment pointed to a role of the government in macroeconomic stabilization. It also pointed to a new view of inequality. The fact that poorer people tended to have a higher marginal propensity to consume out of extra income implied that lower inequality would promote growth, until full-employment was reached (Keynes 1935, Chapter 24). ${ }^{20}$ Keynes did not say much about poverty explicitly. However, in an essay published in 1930, he was optimistic that "the economic problem," which he identified as "the struggle for subsistence," would be solved within 100 years, by 2030 (Keynes 1930, p.4). Keynes also advised on antipoverty policy.

The mid- $20^{\text {th }}$ century saw serious discussions of the idea of ending poverty. ${ }^{21}$ The socioeconomically unequal sacrifices of WW2 left a popular appetite for progressive policies, including more inclusive social protection schemes. ${ }^{22}$ A landmark report by the economist and politician William Beveridge (1942) outlined radical new policies for social insurance, family allowances and income support in Britain. (Keynes supported Beveridge's plans, but with concerns about how they would be financed, including the family allowances.) The aim was to end poverty, but Beveridge was opposed to means-testing; universal provision was seen to encourage social cohesion. In due course, this would mark the end of England's highly stigmatizing workhouses.

From soon after WW2, U.N. reports and resolutions were mentioning the need to eradicate poverty. ${ }^{23}$ Article 25(i) of the U.N.'s 1948 Universal Declaration of Human Rights states that "Everyone has the right to a standard of living adequate for the health and well-being of himself and of his family, including food, clothing, housing and medical care and necessary social services, and the right to security in the event of unemployment, sickness, disability,

\footnotetext{
${ }^{20}$ On other discussions of poverty and antipoverty policies in Keynes's writings see Pressman (1991).

${ }^{21}$ Beaudoin (2007, p.100) dates the idea of ending poverty to the period after WW2. As we have seen, the idea had deeper intellectual roots going back to the $18^{\text {th }}$ and $19^{\text {th }}$ centuries.

${ }^{22}$ Scheve and Stasavage (2016) argue that the war created a desire for higher top marginal tax rates as compensation for unequal sacrifice during the war. Of course, that would depend on how the extra revenue was spent.

23 The earliest example I have found is an official UN document from 1947.
} 
widowhood, old age or other lack of livelihood in circumstances beyond his control." This was a lofty aspiration —-well intentioned no doubt, but (like many other rights-based decrees) largely devoid of content on what it meant or how it would be attained.

In the wake of WW2, many "developing countries" broke free from their Colonial masters who (among other concerns) had not been seen to be making any serious effort to end poverty. The first governments of the newly independent states mostly espoused that goal, though it took time to see much success. On the eve of India's Independence, Prime Minister Jawaharlal Nehru's (1947) Tryst with Destiny speech to the first parliament defined the "service of India" as the "...ending of poverty and ignorance and disease and inequality of opportunity." India made progress on many fronts over the subsequent decades, including in the measurement of poverty, not least due to the introduction of its National Sample Surveys from 1950, founded by the globally renown statistician P.C. Mahalanobis, and pioneering work by Dandekar and Rath (1971, Bardhan and Srinivasan (1974) and Sen (1976), amongst others. Democracy helped promote antipoverty policies, though the policies were not always adapted well to the capacities of government to deliver, especially in poorer states. ${ }^{24}$ There have long been hints of symbolic goal-setting. Alas, a sustained reduction in the incidence of poverty was not one of India's many accomplishments in the 40 years after Independence; progress was slow until the mid-1980s (Datt et al. 2020). India's lack of progress against poverty in the decades after Independence was not in the main because of rising inequality; rather it was associated with weak economic growth.

The post-WW2 period also saw "development" become a mainstream topic. New fields of study emerged, along with new policy issues, new portfolios in government and new international organizations, including the World Bank. At first, poverty reduction did not figure prominently. This would change.

\section{The Second Poverty Enlightenment}

The 1960s and '70s saw an explosion of attention to the idea of ending poverty. ${ }^{25}$ This is the Second Poverty Enlightenment (Ravallion, 2015). It was a global change in thinking. The U.N. gave expression to post-Colonial ambitions to be free of poverty by declaring the 1960s to

\footnotetext{
${ }^{24}$ See, for example, Dutta et al. (2014) on the performance of India's National Rural Employment Guarantee Scheme in one of the poorest states, Bihar.

${ }^{25}$ Again, see the Google Ngram Viewer. Notice that from the early 1980s, usage shifted from "eliminating poverty" to the somewhat less tame terms "eradicating poverty" and "ending poverty."
} 
be the (first) "Development Decade." As UNICEF (1961) put it: "The countries of the 'third world', having cast off their colonial status, now also needed to cast off their poverty." This signaled the beginning of a broadening of focus from thinking about "development" as little more than economic growth to embracing poverty reduction and human development. The International Labour Organization (ILO) began emphasizing the attainment of "basic needs" (such as adequate food, health-care, safe drinking water) as development priorities (ILO 1976). Higher incomes only mattered to the extent that they delivered these basic needs. The World Bank made Poverty and Human Development the topic (and title) of its 1980 World Development Report. This period also came with the emergence of development economics as a field, and development studies more broadly. The academic journals World Development and the Journal of Development Economics were launched in 1973 and 1974 respectively.

All this marked a significant change in development thinking, with lasting influence (which Section 6 returns to). However, looking back, what was happening in America from the early 1960s stands out historically for combining the idea of ending poverty with a concerted effort to do so. To some extent, it might be said that America was catching up with Britain and much of Western Europe in terms of antipoverty policies. However, America's story illustrates broader global themes of the period, albeit with some special features.

The post-War period had seen sustained growth in average living standards in America. That growth came with lower poverty rates overall, but also brought structural transformations of the economy, notably the mechanization of agriculture and displacement of large numbers of southern workers, moving into the North's cities. The context of rising average living standards also meant that poverty was seen as a national disgrace, calling for a political response.

Nor was rising general affluence seen to have done enough to redress the historical racial inequalities of America - inequalities that were correlated with poverty but with their own distinct history and causation in a setting of deeply embedded racism. In the county's history, that feature of America would often make it harder to form an effective coalition against poverty. Common ground did become evident in the 1960s when the Civil Rights Movement turned to the challenges of ending poverty - recognizing that the lack of civil rights was among the causes of poverty in America, but also acknowledging common class interests across different racial and ethnic groups. As at other times in history, the context of perceived overall affluence sharpened the call to action against poverty. As Martin Luther King put it in his acceptance speech for the 
1964 Nobel Peace Prize: "There is nothing new about poverty. What is new, however, is that we have the resources to get rid of it."

Social commentaries had played a role. Michael Harrington's (1962) graphic portrayal of the lives of poor Americans in The Other America was an unexpected best seller. ${ }^{26}$ Economists also played a role. John Kenneth Galbraith (1958) (and Harrington) described the new "minority poverty" in America. With economic growth, the "old poor" had joined an expanding middle class, but others were left behind or thrown into poverty from which they could not escape. In 1964, the renown Swedish economist Gunnar Myrdal gave a talk at Georgetown University calling for a "Marshall plan to eradicate poverty" (Hunter, 1964). (Myrdal also advised against explicitly special treatment for Black Americans, arguing that there would be a backlash from some white Americans.) Myrdal was clearly trying to influence President Johnson's War on Poverty (building on President Kennedy's prior initiative), to be announced to Congress soon after Myrdal's talk.

The goal of the War on Poverty was explicitly to end poverty, though no official target date was given. The policy objectives were framed by the idea that economic growth would be the main driver of poverty reduction, and the main policy challenges were how to assure that America's poor were equipped to participate in that growth, and thus contribute to it. The new policy initiative was presented in a context of rising affluence and falling poverty, but called for an extra push, to "redouble and to concentrate our efforts to eliminate poverty" (Johnson 1964, p.55). That was a politically appealing way to frame the problem. As Alice O'Connor (2001, Chapter 6) notes, terms such as "inequality" and "redistribution" were avoided, though inequality of opportunity was emphasized. To some degree, this was more about packaging than substance; the policy instruments of the War on Poverty were in no small measure redistributive.

A host of new federal programs emerged, as part of this effort. Getting poor people into jobs was seen as important, but the emphasis of the War on Poverty programs was more on the supply side of the labor market. (Side-by-side with the War on Poverty there were aggregate fiscal efforts to help assure full employment.) The antipoverty programs covered nutrition (food stamps), health (Medicare and Medicaid), education (including in early childhood), housing, training and various community-based initiatives, with more or less explicit empowerment goals.

\footnotetext{
${ }^{26}$ Other efforts to describe poverty emerged around this time; for example, in Britain The Poor and the Poorest, by
} Brian Abel-Smith and Peter Townsend (1966) was influential. 
Some of the programs continue to this day. Pre-existing transfers targeted to poor families continued, the largest being Aid to Families with Dependent Children (AFDC).

New knowledge had helped make possible this heightened awareness of poverty and how to respond to it, and that knowledge would inform policy responses. The First Poverty Enlightenment lacked the theories and data that we take for granted today in trying to understand poverty and so inform public action. That had changed by the late 1950s. Researchers and policy makers could formulate arguments grounded on a body of both theory and data. The latter included qualitative studies, such as Harrington's, but we saw studies using large sample surveys and analytic work in measuring living standards and setting poverty lines. Many people were shocked to learn in the early 1960s when the official calculations indicated that almost one-infive Americans lived in poverty, and half of Black Americans.

The expertise that was brought to bare on the problem of poverty in America was impressive by any standard. A review of the War on Poverty 50 years later by a group of eminent economists working on poverty in the U.S., described the chapter of the 1964 Economic Report of the President (Johnson 1964), commissioned by Johnson to initiate the effort, as "...a landmark of poverty analysis to this day" (Haveman et al. 2015, p.594). A Task Force with 130 members was created, and produced the key legislation in six weeks. An offshoot was the creation of the Institute for Research on Poverty at University of Wisconsin-Madison.

Some commentators viewed this new "poverty knowledge" with suspicion, arguing that it was deliberately focused on individual behavior, deflecting attention from deeper "structural" inequalities. With reference to the feminization of poverty in America, O'Connor (2001, p.254) contrasts "mainstream poverty studies" that "individualized and decontextualized the problem" with approaches that pointed to "long-standing gender inequalities in the welfare system, the family, and the labor force." While these critiques highlighted a genuine concern, the newly emerging scientific tools for the study of poverty could also help better understand the deeper constraints on behavior, associated with socioeconomic inequalities in multiple dimensions. The fact that one studies poverty with households as the primary unit of observation does not imply that one thinks that poverty is solely due to bad choices by individuals. Drawing on these and other new tools of analysis (including various modelling tools), a new poverty knowledge-base was emerging, including studies of the workings of labor and credit markets, and the origins of specific dimensions of poverty, such as associated with discrimination by race and gender. 
The idea of a guaranteed minimum income had been on the menu of options in the War on Poverty. One version of the idea was proposed by Milton Friedman, (1962), namely a Negative Income Tax. This was an extension of Bentham's idea of exempting from taxation all incomes below some critical level (the "subsistence income" for Bentham), with the difference was that in Friedman's proposal tax revenues and/or savings from other welfare spending would be used to bring everyone up to the subsistence level. This is equivalent to a UBI (such as Paine had proposed) financed by a progressive income tax. Note, however, that Friedman's proposal was intended to replace existing welfare programs, so (to the extent these benefited the poor) the size of the gains to poor families was unclear, and some may even end up worse off. A complete accounting of how a UBI is to be financed is crucial to evaluating the idea (Atkinson 1995).

In the late 1960s, America came close to implementing a form of income guarantee under (surprisingly) President Nixon in 1969 (Steensland 2008). Nixon's “Family Assistance Plan" was not a UBI, but nor was it a means tested minimum-income scheme, with high marginal tax rates. Nixon's plan provided a uniform payment below a certain income, then tapering off at a $50 \%$ marginal tax rate. ${ }^{27}$ (The scheme was to be financed in part by abolishing AFDC.) Initially, there was no distinction between "deserving" and "undeserving" poor, or "unemployed" versus "working poor;" being poor determined eligibility. This was an important break from thinking about antipoverty policies in America and elsewhere which identified the "undeserving poor" as those judged to be poor for lack of work effort. ${ }^{28}$

Nixon's plan was squashed by an advisor, Martin Anderson, quoting Polanyi's (1957) interpretation of the 1834 Royal Commission report on the adverse incentive effects of the Speenhamland scheme (Section 3). ${ }^{29}$ Even if one accepted the historical record on Speenhamland, the two schemes would have very different incentive effects given that Speenhamland implied (on paper at least) a 100\% marginal tax rate on poor people, rather than zero or $50 \%$ as in Nixon's scheme. Nor is there any evidence that Nixon's advisors had read Blaug's (1963) paper. ${ }^{30}$ If they had then they may have stopped to question whether the prevailing historical record on Speenhamland was accurate, although that record clearly served a

\footnotetext{
${ }^{27}$ See the description in Lampman (1971, p. 162).

${ }^{28}$ See the discussions in Katz $(1987,1996)$ and Gans (1995).

${ }^{29}$ Anderson (1978, Chapter 5) appears to contain the substance of his advice to Nixon some 10 years earlier. For further discussion see Steensland (2008, Chapter 3) and Bregman (2017 Chapter 4).

30 There is no mention of Blaug's work in Anderson's (1978) representation of the debate at the time.
} 
political objective for the opponents of welfare reform. (Writing 10 years later, Anderson, 1978, repeated his analogy between Nixon's plan and the Speenhamland scheme.)

In 1972, Nixon put up a modified version including work requirements - that able-bodied beneficiaries must register with the Department of Labor to seek work. Thus, the idea of "undeserving poor" crept back in. Despite its apparent popularity with the press and public (Steensland 2008, p.123), the legislation did not pass the Senate. Opposition came from multiple sources. Some did not support the gender and racial equalization implied by the policy. Others saw the work requirements as racist. And some felt that the benefit level was too mean. Something similar did emerge later (in 1975 under President Ford), namely the Earned Income Tax Credit, which gives income support to low-wage workers (indexed and adjusted for family size) via the federal income tax system; this continues today, with broad (bipartisan) support.

The importance of economic growth versus income redistribution remained a contentious issue in thinking about how best to fight poverty. In a report to the U.S. Congress, the economist Robert Lampman (1959) — one of the architects of the Johnson Administration's War on Poverty - made a calculation based on survey data for two dates (1947 and 1957) indicating that the poverty rate in America had fallen from 26\% to 19\%. Heroically projecting this forward, he predicted that poverty would be "virtually eliminated" in 30 years. Lampman saw economic growth as the main driver of progress against poverty, though he also recognized the need for redistributive social policies. The post-WW2 growth had come with falling inequality, and Lampman did not appear to think there was any prospect of that changing.

In contrast, Galbraith (1958) did not expect that U.S. economic growth would have much impact on poverty, as it had evolved to be concentrated among groups of people who (he argued) would gain little from rising average productivity. Galbraith put emphasis on the need for targeted redistribution, while Lampman saw good prospects for ordinary growth to continue to reduce poverty, in combination with social policies. This debate between Lampman and Galbraith would echo across the world.

The idea of relative poverty also emerged in this period. The American economist Victor Fuchs (1967) proposed that the poverty line should be set at 50\% of the current median income. This naturally puts greater weight on reducing inequality; indeed, an immediate implication of setting a poverty line as a fixed proportion of the current median or mean is that when all income levels rise by the same proportion the measure of poverty remains unchanged despite the 
absolute gains to poor people. ${ }^{31}$ Any process of economic growth that does not change relative inequality will leave the poverty measure unchanged. The Fuchs proposal was later adopted by Tony Atkinson (1998) in describing poverty in Europe, and was used by Eurostat and the OECD.

The U.S. War on Poverty targeted instead absolute poverty, judged by a fixed real line over time. Lampman (1971, p.53) acknowledged that "income poverty is a relative matter" yet used an absolute line (fixed in real terms), echoing Bowley (1915). Lampman saw the inconsistency, but argued that, once absolute poverty is eliminated, the next generation can pick a higher real line, and move on to the task of ending poverty by the new line. (Lampman makes no mention of Rawls (1971) but his reasoning can be thought of as an operationalization of the "maximin" criterion - to maximize the welfare of the least advantaged person.) However, it is surely a questionable response to say that (in essence) "yes, poverty is relative" but "we can ignore that now and let the next generation worry about it." Neither the next, nor the next, generation saw the end of poverty and new official poverty lines. ${ }^{32}$ What Lampman implicitly recognized is that there is strong political resistance to revising poverty lines. ${ }^{33}$

Neither absolute nor relative lines set at a constant proportion of the mean or median can be justified if people care about both their absolute level of living and their income relative to others in the country of residence (Ravallion 2020c). A better option is to accept that poverty lines should rise with a sustained increase in average income, but not in a directly proportional way - that the line is "weakly relative," with a strictly positive lower bound.

The official line in the U.S. has remained an absolute line over time, only updating the original lines developed by Mollie Orshansky (1965) for inflation using the (urban) Consumer Price Index. It seems likely that the level of real income below which people in America today think that they are "poor," and above which they do not, is greater than the current official poverty line. The absolute poverty line used for America by Hunter (1904) appears to be less than one tenth of the current official line (Ravallion, 2016a, Chapter 1). The reason the line has not risen despite the increase in average living standards is more to do with politics (Blank 2008).

\footnotetext{
${ }^{31}$ Since the idea first appeared, some have claimed it to be impossible to end relative poverty-it would always be with us. Yet there is no theoretical reason why the distribution of income could not be such that nobody lived below half the mean (say). Whether that could be politically feasible in practice is another matter, as with absolute poverty.

32 Though proposals were made; see Watts (1986), Citro and Michael (1995) and Blank's (2008) review.

${ }^{33}$ Blank (2008) explains this more fully in the U.S. context.
} 
A second new direction in poverty measurement emerged around this time, namely the effort to incorporate information on the distribution below the poverty line, giving various "higher-order" measurers. A first step was taken by Harold Watts (1968), who had worked in the US government on the War on Poverty (and was the first Director of the Wisconsin Institute). Watts proposed that instead of using the proportion below the line it would be better to measure the mean proportionate poverty gap, thus (implicitly) penalizing income inequality among poor people. In the 1970 s and ' 80 s a series of papers developed firmer theoretical foundations for measurement and new measures. ${ }^{34}$

Poverty in America did not end by 1990. Some blamed the antipoverty programs, and a backlash against those programs emerged in the 1980s. Famously, President Raegan said (in a 1988 address to Congress) that "the Federal Government declared war on poverty and poverty won." The main proximate cause of the slowdown in progress against poverty was not lack of economic growth (though the late 1970s and early 1980s had seen low growth, and high inflation rates). Nor did the programs fail; poverty rates tended to fall after the War on Poverty began, up to the late 1970s, and the poverty measures would almost certainly have been higher without the programs (Haveman et al. 2015). ${ }^{35}$ The evidence suggests that some of the major programs, such as Food Stamps, have helped reduce poverty (Jolliffe et al. 2019).

Rather, the proximate reason for the lack of progress against poverty in America from the 1980s onwards was that rising inequality in market incomes did not come with sufficiently enhanced redistributive effort. ${ }^{36}$ This was a political change. We would no longer hear about the efforts of a Republican President in the late 1960s to end poverty using the welfare state; instead, we would see reforms backed by a Democratic President in the mid-1990s that were seen by their critics as a threat to the welfare state. ${ }^{37}$ Growth would continue, but it would bypass a great many poor people. In America, the Second Poverty Enlightenment had a disappointing aftermath, like the First. In retrospect, Galbraith was closer to the truth than Lampman.

\footnotetext{
${ }^{34}$ Contributions came from Sen (1976), Foster, Greer and Thorbecke (1984) and Atkinson (1987). The Foster et al "squared poverty gap" has been the most widely used distribution-sensitive index. As it turned out, the original Watts index satisfied the proposed axioms for a good measure (Zheng 1993), but it has not been widely used. 35 This can be assessed using the US Census Bureau new Supplemental Poverty Measures, which take a more complete account of the in-kind programs and benefits though the tax system. The official poverty measures (based on pre-tax cash income) do not show this decline. See Haveman et al. (2015, Figure 1).

${ }^{36}$ Over time the effort switched from cash to in-kind transfers and tax-linked support (Haveman et al. 2015), and also to those seen to be the "deserving poor," notably the elderly and disabled (Moffitt 2015).

${ }^{37}$ The reforms under President Clinton in the mid-1990s imposed work requirements on many welfare recipients including AFDC, which then contracted substantially (Haveman et al. 2015)
} 
While these changes were happening in America, no less dramatic changes in thinking about poverty were beginning in the developing world. These too had a history.

\section{Ending poverty becomes a development goal in the late $20^{\text {th }}$ century}

While the Second Poverty Enlightenment in the 1960s and '70s saw much greater attention to global poverty, the debt crises of the1980s saw the near-term priorities of many governments and the International Financial Institutions switch to macroeconomic stability and restoring economic growth. These were also important for poor people, but why that was so, and the implications for the design of macroeconomic adjustment programs - the composition of the public spending cuts and the tax reforms-were clearly not given enough attention initially. While the 1980s had begun with a WDR on poverty and human development (World Bank 1980), this focus largely slipped from view at the World Bank. ${ }^{38}$ Adjustment with a Human Face was soon needed, as in the title of an influential volume by Cornia et al. (1987).

The late 1980s saw renewed attention to global poverty. On October 17, 1987, more than 100,000 people gathered in Paris, at the Trocadéro, where the Universal Declaration of Human Rights had been signed some 40 years earlier. They were there to recognize those who suffered from poverty globally. Since then, October 17 has been the International Day for the Eradication of Poverty. Soon after, the World Bank (1990) released its new WDR, simply titled Poverty. This was influential in development policy circles, especially, but not only, within the Bank. Not long after, a "world free of poverty" became the Bank's overarching goal. Poverty reduction started to be seen as a core element of economy-wide reform programs, rather than being added on as a tranquillizer after the fact.

The focus on promoting economic growth in poor countries remained in the 1990s, but with two main differences. First, growth was not seen as the objective, but rather the right sort of growth was seen as a means of reducing poverty. New attention was given to pro-poor technical progress, a prime example of which had been the Green Revolution in South Asian agriculture, which assured rising productivity in the sector where the poor tended to be concentrated as smallholders or workers. ${ }^{39}$ Second, it was argued that there were important complementarities

\footnotetext{
${ }^{38}$ An exception was World Bank (1986), though the focus was more on food security, with emphasis on costeffectiveness.

${ }^{39}$ This too was debated at the time although the evidence supports the view that the Green Revolution was poverty reducing; for further discussion and evidence see Lipton and Longhurst (1989) and Datt and Ravallion (1998).
} 
between pro-poor growth and social policies promoting human development and social protection, both of which expanded within the Bank's lending program and policy engagements.

Echoing the Johnson administration's War on Poverty, the fact that the 1990 WDR gave prominence to economic growth as the route to poverty reduction in the developing world helped assure its broad base of influence. Not much was said in the Bank's more high-profile publications about "inequality" or "redistribution" in the 1990s, though research continued, such as by Francisco Ferreira and Branko Milanovic. In time, these topics were addressed in a more prominent way by the Bank, notably in its 2006 WDR, Equity and Development (World Bank 2006), although with emphasis on inequality of opportunity, rather than inequality of outcomes; this emphasis clearly helped assure broader acceptability across the political spectrum, although the two sorts of inequality are not so easily separated.

The Second Poverty Enlightenment saw a consensus that "growth is necessary but not sufficient for poverty reduction," as put by the World Bank's first Chief Economist, Hollis Chenery (1977, p.v). Strictly, this was never correct, since incomes can be redistributed to reduce poverty without growth. What was meant is that growth creates a potential for poverty reduction provided it comes with the conditions needed to assure that poor men and women can participate in, and contribute to, that growth. ${ }^{40}$ That was a message with broad appeal. Differences in emphasis remained, even within the World Bank's research department, as reflected in the titles of two papers by its staff that came out in the early 2000s, one entitled "Growth is Good for the Poor" (Dollar and Kraay 2002) and the other "Inequality is Bad for the Poor" (Ravallion 2005).

The perspective on trade-offs was also changing in the new Millennium. New research cast doubt on the view that there was a necessary trade-off between lower inequality and higher growth. A stylized fact about growth processes in developing countries is the weak correlation between growth rates and changes in inequality. ${ }^{41}$ During spells of growth, inequality increased about as often as it fell. This implied another stylized fact, that poverty rates tended to fall with growth. However, it was also learnt that whether inequality rose or fell during spells of growth matters to the pace of poverty reduction (Ravallion 2001). Even when inequality was not increasing, differences in initial inequality were found to be important to both how much growth

\footnotetext{
${ }^{40}$ See, for example, Chenery et al. (1974).

${ }^{41}$ This was demonstrated in Ravallion (2001) and re-affirmed in Ferreira and Ravallion (2013).
} 
would reduce poverty and how much growth actually occurs. High initial inequality tends to both retard growth and make the growth that does occur less pro-poor. ${ }^{42}$

A point that is often missed in this debate is that the relative weight on these two broad avenues for policy is likely to depend on the stage of economic development. It is plausible that there is greater scope for redistribution in richer countries. The tax rates on the non-poor needed to eliminate poverty in poor countries are likely to be very high. This can be measured by implementing a version of the Bentham-Friedman idea for income taxation, namely by calculating the marginal tax rate on those who are not poor by rich-country standards that is needed to cover the poverty gap or to provide a poverty-level of basic income, judged by developing-country standards (Ravallion 2010). One finds that for most (but not all) countries with annual consumption per capita under $\$ 2,000$ (at 2005 PPP), the required tax burdens are likely to be prohibitive - often calling for marginal tax rates of 100 percent or more. By contrast, the required tax rates are quite low (1\% on average) among all countries with consumption per capita over $\$ 4,000$, as well as some poorer countries. Most countries fall into one of two groups: those with little or no realistic prospect of addressing poverty through redistribution and those that would appear to have ample scope for this. Economic growth tends to move countries from the first group to the second. Thus, the appropriate balance between growth and redistribution strategies can be seen to depend on the level of economic development, and to change over time.

The push-back against the neglect of human development in the 1980s (in the rush for macroeconomic adjustment) led to greater recognition of the fact that command over commodities is not all that matters to human welfare. Amartya Sen (1985) provided a broader framework for thinking about "well-being" that encompassed real income with other factors relevant to human capabilities, defined as the set of attainable functionings in life, which ultimately determine one's freedom (Sen 1999). This provided a conceptually appealing theoretical framework. Of course, the fact that one measures poverty in the space of real income does not mean that real income is all that matters to welfare; that is also a matter of how one sets the poverty line, which can reflect other aspects of welfare. However, poverty measurement practice has typically ignored some key aspects of welfare, including access to non-market goods, intra-household inequalities and relative deprivation.

\footnotetext{
${ }^{42}$ For evidence supporting these claims see (Ravallion 1997, 2005 2012).
} 
Two approaches to these "non-income" dimensions of poverty emerged. The first identified a dashboard of indicators, while the second entailed forming a composite index of multiple indicators. ${ }^{43}$ Both recognize the risk of ignoring the "non-income" dimensions, but there was also a risk of too long a list of indicators. This echoes a concern raised by Harold Watts (1968), in the context of the Johnson administration's War on Poverty, namely that if every program is required to address every dimension in some long list it is possible that every program will be deemed a failure, even when the whole package is a success. Forming a single composite index seems to solve this problem of an excess of dimensions, but it typically does so in an ad hoc way, forming a "mashup index" with no obvious basis for knowing the relative weights; indeed, in some cases the relative weights were never even calculated, and could be shown to have perverse properties (Ravallion 2016a, Chapter 5). A composite index could also be worryingly attractive to a government that was doing badly in one dimension; by folding that lagging dimension into others the poor performance could be better hidden. The dashboard of indicators is clearly more useful for guiding policy.

The original " $\$ 1$ a day" poverty measures were based on data for only 22 developing countries (Ravallion et al. 1991). The 30 years since have seen a huge expansion in primary data collection; here the efforts of national statistics offices have been crucial, often supported by international agencies (such as the World Bank's Living Standards Measurement Study). The latest global poverty measures draw on over 1500 surveys for over 150 countries. Similar efforts went into monitoring non-income dimensions of welfare (such as USAID's Demographic and Health Surveys). Efforts also went into improving data access, both to primary survey data (though some countries are lagging in providing public access) and through data tools, such as in the World Bank's interactive platform for global poverty measurement, PovcalNet.

MDG1: The U.N.'s Millennium Development Goals (MDGs) were officially launched in 2000. The dashboard of multiple goals emerged from much debate. Every international agency got into the act, keen to have its own agenda promoted as one of the MDGs. The first goal (MDG1) was to halve the 1990 "extreme poverty rate" by 2015.

Some commentators greeted the MDGs with unbounded enthusiasm (such as Sachs, 2005); others derided them as "utopian" distractions (such as Easterly, 2006); yet others thought

\footnotetext{
${ }^{43}$ The World Bank's annual World Development Indicators exemplify the dashboard approach; examples of the composite index approach include the UNDP's Human Development Index and the Alkire and Foster (2011) index.
} 
they took too much for granted (such as Saith, 2006). The goals were well intentioned. As Hulme (2009, p.4) puts it, they aimed to "stretch ambitions and mobilize political commitment and public support." Widespread support followed. For example, a new coalition formed in the U.K., "Make Poverty History." (Their famous "click ad," pointed out that every three seconds a child somewhere in the world dies from preventable causes. ${ }^{44}$ ) Another example was the Global Call for Action Against Poverty; 173 million people globally took part in their "Stand Up Against Poverty" on the International Day for the Eradication of Poverty, 2009.

While all this was going on, the developing world was quietly making progress against poverty. Figure 1 gives a plot of global poverty rates using the $\$ 1.90$ line over 1981-2015. The long-term decline is almost exactly $1 \%$ point per annum, though uneven over time. Progress slowed in the late 1980s but accelerated after 2000 (as one can see comparing the trajectories before and after 2000). China's success against poverty was part of the reason, but poverty rates fell in all regions after 2000. Using the $\$ 1.25$ poverty line at 2005 PPP, MDG1 was attained in 2010, five years ahead of time (Chen and Ravallion, 2012).

Figure 1: Global absolute poverty rates, 1981-2015

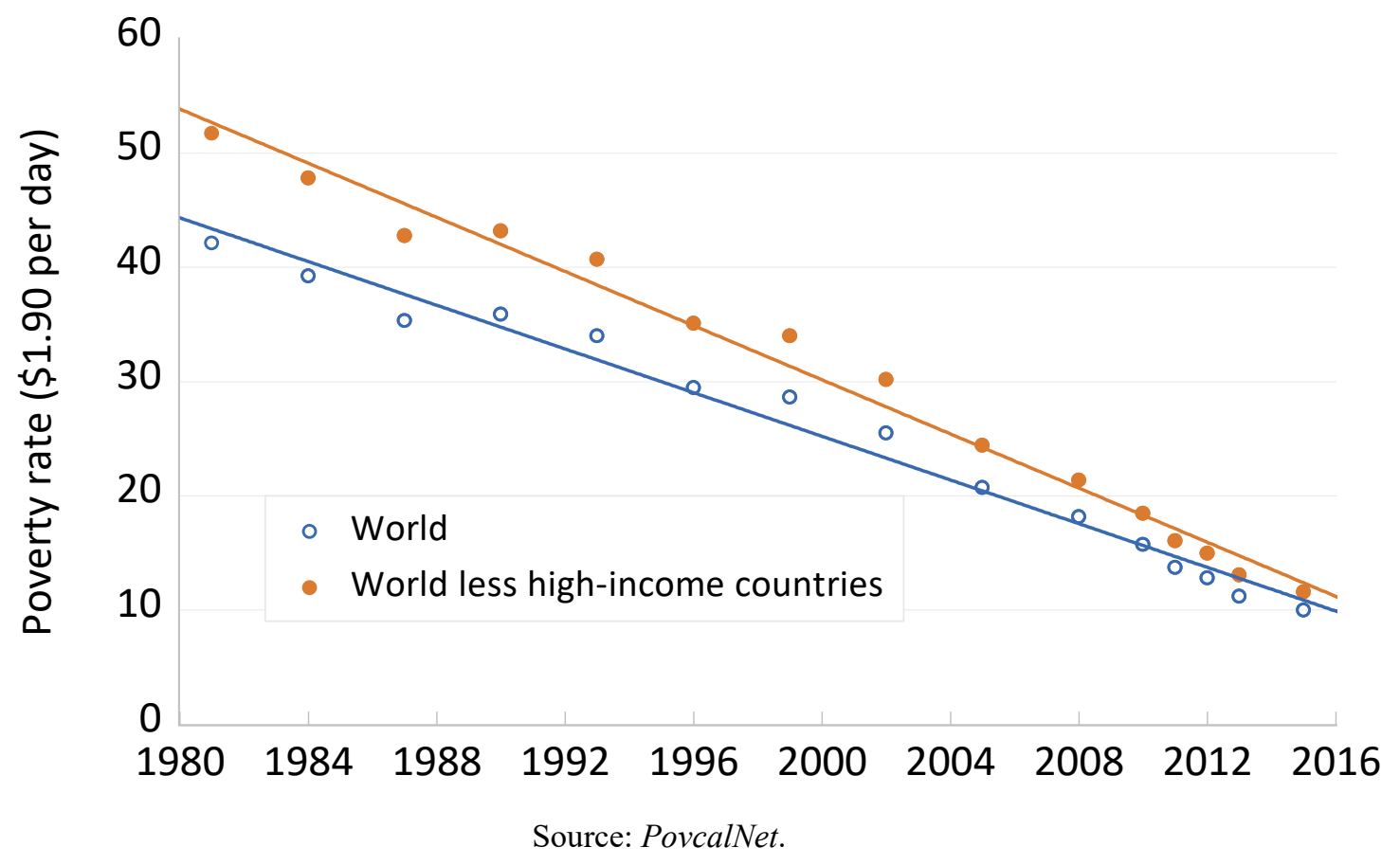

${ }^{44}$ In a bizarre footnote to this history, in 2005, the UK government's Office of Communications, banned these ads as being "wholly or mainly political" in nature (Guardian, 2005). 
In principle, the poverty rate could be halved without any gain to the poorest half of the poor. The reasons that the poorest are the poorest can involve higher costs in reaching them, including in realizing their participation in the growth process. The poorest often have the least political influence, and altruistic motives may well be stronger toward people not too far below one's own level of living (possibly with some shared identity). One might not be surprised to also find that the poorest are often left behind.

This poses a serious concern about the framing of MDG1. With the benefit of hindsight, we can now see evidence to support that concern. Figure 2 shows both the overall mean household real income in the developing world and the estimated level of the floor-the expected value of the lowest level of mean consumption. ${ }^{45}$ The decline in the poverty rate evident in Figure 1 came with very little progress for the poorest.

\section{Figure 2: Consumption floor and overall mean 1981-2015}

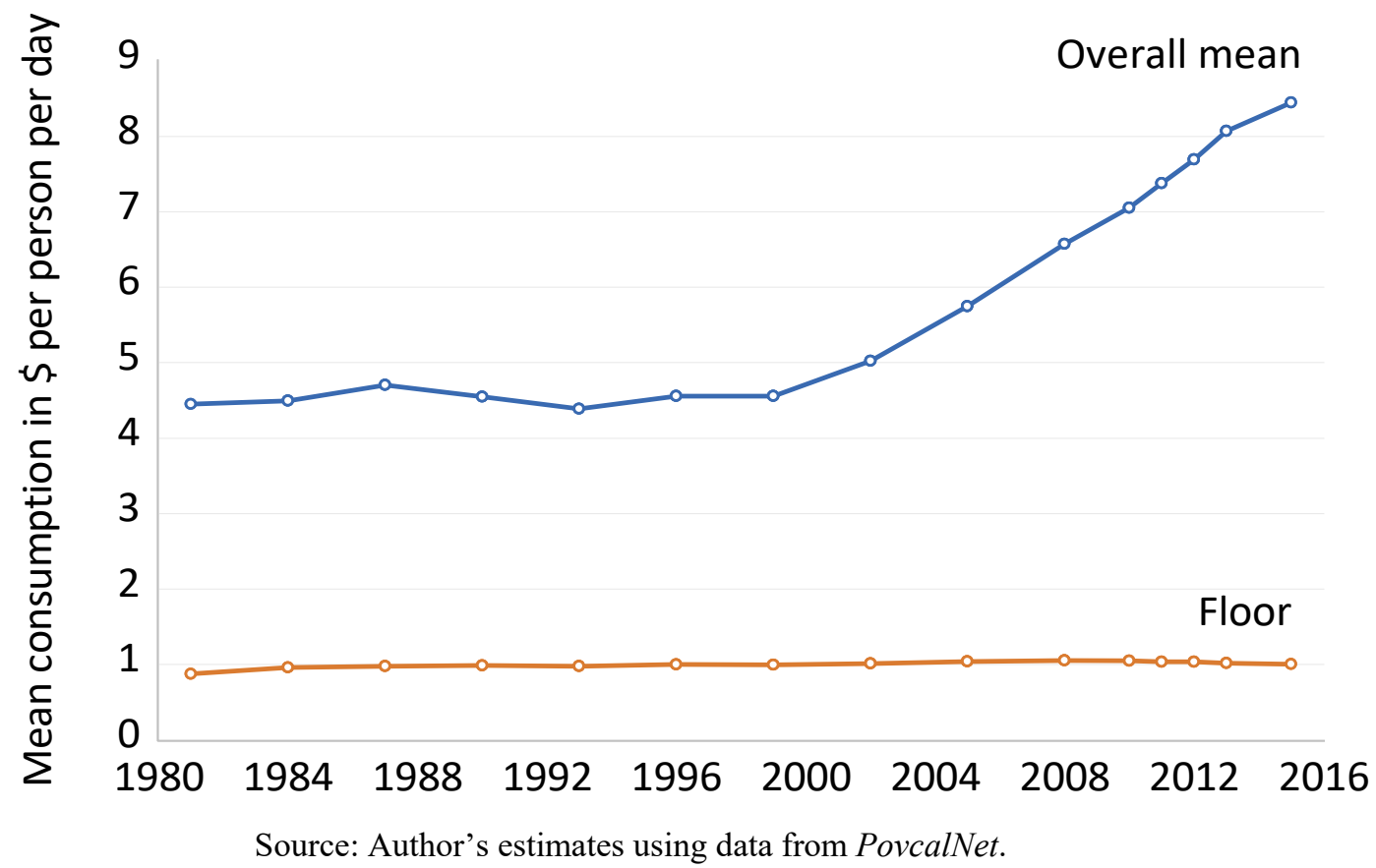

The Galbraith-Lampman debate resurfaced often in development policy discussions.

While Lampman had not anticipated the rise in US inequality, his position in that debate is more consistent with what we have seen in the developing world. Figure 3 plots the proportionate rate

${ }^{45}$ Figure 2 uses the estimator of the floor proposed by Ravallion (2016b), which also discusses robustness to alternative measurement assumption; Ravallion (2020d) gives results using only consumption surveys. 
of "\$1.90-a-day" poverty reduction against the GDP growth rate, both over the MDG period, 1990-2015. Of the 86 countries with positive growth (versus 12 with contraction), the poverty rate fell for 77, with only 9 experiencing growth with rising poverty. The regression line has a slope of -1.66 (with a standard error of $0.20 ; n=98$ ), which is interpretable as the average elasticity of poverty reduction to economic growth. ${ }^{46}$ The (often repeated) pessimism about the prospects for poverty reduction in growing economies does not hold up against Figure 3. Of course, there is still a variance in rates of poverty reduction at a given rate of growth. This includes measurement errors, but it also reflects cross-country differences in the type of growth (for example, its sectoral and geographic pattern) and initial conditions (including inequality).

\section{Figure 3: Growth and poverty reduction across countries 1990-2015}

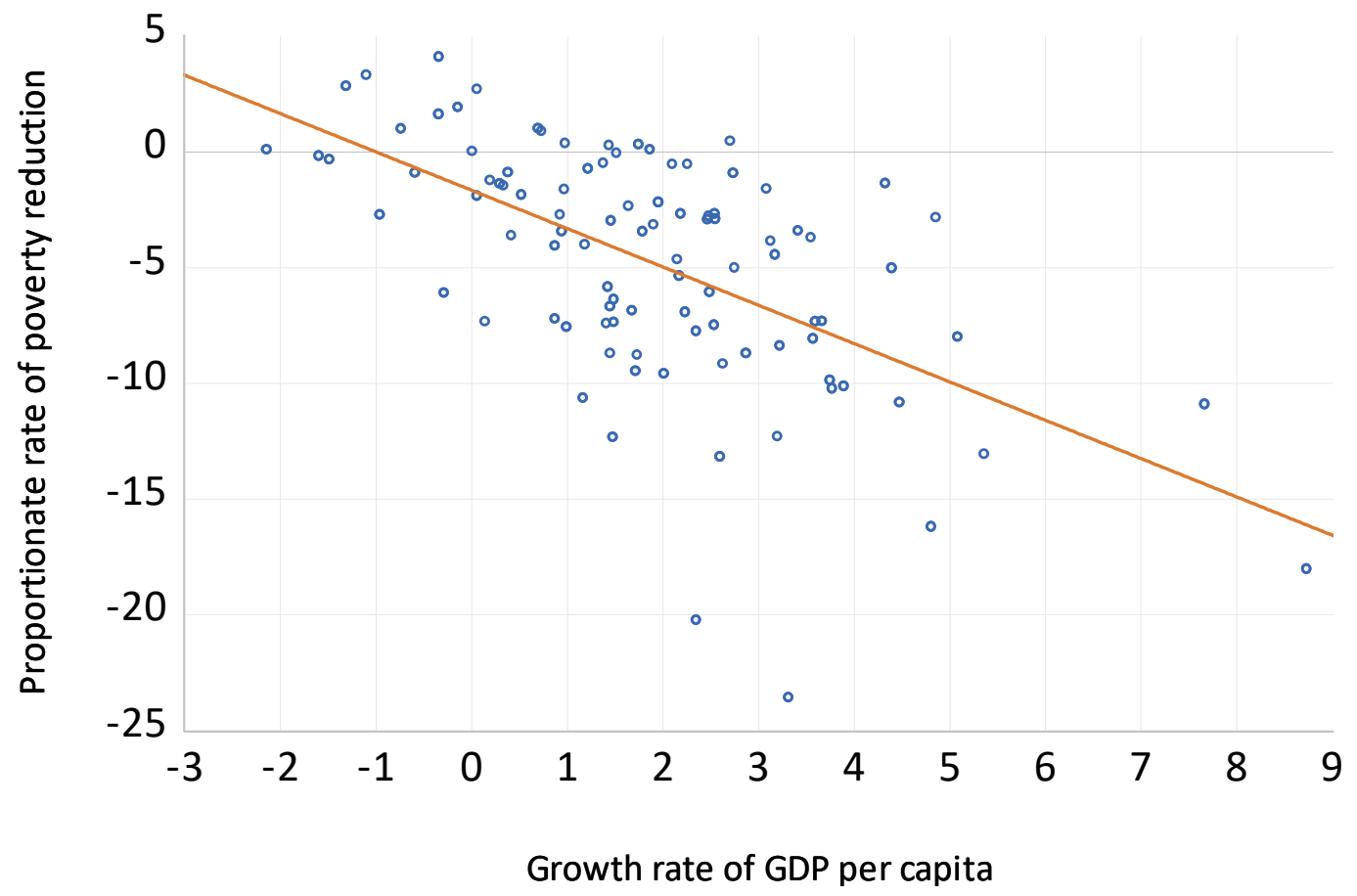

Note: Annualized log differences times 100 for all spells with a 1990 poverty rate of $2 \%$ or higher. Source: Author's calculations using data from PovcalNet and the World Development Indicators.

Some observers read too much into the type of correlation in Figure 3. It does not tell us that any growth-promoting policy will reduce poverty; that depends in part on what the policy does to inequality. (As noted, while growth rates are only weakly correlated with inequality

\footnotetext{
${ }^{46}$ National accounts data do not match survey periods well and the resulting measurement errors are likely to attenuate the regression coefficient. If instead one uses the mean consumption or income from the surveys (which match the poverty measures exactly) the regression coefficient is -1.84 (with a standard error of $0.20 ; n=103$ ). Using the survey means the poverty rate fell in 82 out of the 84 countries with positive growth in the survey mean.
} 
changes, the latter still matters a lot to the change in the poverty rate.) Also, the causality could well go in the opposite direction, whereby success in reducing poverty helps promote growth (as indicated by the evidence assembled in Ravallion, 2012, who pointed to both credit market failures and child underdevelopment in poor families as explanatory factors). Also, if one focuses on shorter periods then the correlation in Figure 3 is weaker, and more cases of growth without poverty reduction appear (Ravallion 2001). And it should not be forgotten that the higher growth rate after 2000 did not come with much progress in lifting the floor (Figure 2).

How much did MDG1 contribute to its own success? Jeffrey Sachs (2005, xxix) claimed that MDG1 was "... a great spur to accelerated progress and increased action." The web site for the SDGs lists as a "key MDG achievement" that "more than one billion people have been lifted out of extreme poverty since 1990." (Over 1990-2015, 1.2 billion fewer people lived below the $\$ 1.90$ line.) Growth rates in the developing world did pick up after 2000 (Figure 2), and the global rate of poverty reduction accelerated (as noted in the discussion of Figure 1). Aid flows also increased and domestic policies improved in many countries.

It is clearly hard to believe that the entire reduction in global poverty over 1990-2015 was due to external aid in support of the MDGs. Other things also changed, including larger private financial flows to developing countries and rising commodity prices. External aid has also had a mixed record. The aid-optimism of Sachs (2005) is in marked contrast to Angus Deaton's (2013, Chapter 7) more qualified assessment. While it can be agreed that aid has at times been wasted in corrupt development projects and illicit financial flows, the best evidence available does suggest that aid has helped, though success depends heavily on domestic institutions and policies. ${ }^{47}$

Another reason to question any claim that the post-2000 progress against poverty was due to the MDGs is that China accounted for about two-thirds of the global reduction in the number of poor over 1990-2015. ${ }^{48}$ It is hard to imagine that the MDGs had much influence in China. ${ }^{49}$ Furthermore, one-third of China's reduction in poverty over 1990-2015 was prior to the MDGs. Nonetheless, goal setting has long been a popular incentivizing tool in China. Ending poverty was a high-profile goal from the mid-1980s (predating the MDGs). The 8-7 Poverty Reduction Plan aimed to lift the remaining 80 million rural poor (judged by the official poverty line) out of

\footnotetext{
${ }^{47}$ For an overview of the arguments and evidence, and further references, see Ravallion (2016a, Chapter 9).

48 This can be readily verified using $\underline{\text { PovcalNet}}$.

${ }^{49}$ As a personal anecdote, when working on poverty in China and visiting often from the mid-1990s until about 2010, I don't recall ever hearing mention of the MDGs among my Chinese counterparts.
} 
poverty by 2000 . This was not attained, but it motivated action, focused primarily on poor-area rural development. In urban China, the Di Bao program aimed (on paper at least) to do what the Speenhamland scheme had intended: to top up all incomes to reach a stipulated (local) Di Bao line. (Similarly to Speenhamland, Di Bao did not work this way in practice, with local officials smoothing transfers in response to income changes; see Ravallion and Chen 2015.) The MDGs may not have helped much in China, but goal setting probably did.

SDG1: The idea of a final push to end extreme poverty had received encouragement from the success of MDG1. The first SDG includes the goal of ending poverty by 2030, as judged by the $\$ 1.90$ a day line (or $\$ 1.25$ in 2005 prices). This evolved out of the World Bank's own stated goal, which was to bring the poverty rate down to 3\% by 2030 (Ravallion 2013). It is not clear how the Bank's "3\%" goal turned into " $0 \%$," but a plausible conjecture is found in the desire (evident throughout the SDG documents) to "leave nobody behind." This motivates ending poverty, not halving it as in MDG1, or reach 3\% as in the World Bank's goal. As we will soon see, this makes SDG1 far more challenging than the Bank's 3\% goal.

The hope that growth could stay at least as pro-poor as Figure 2, underpinned both the Bank's goal and the U.N.'s SDG1. Ravallion (2013) showed that if the higher growth rate in developing countries could be maintained without a rise in global inequality then the $3 \%$ target would be reached. That is also consistent with a simple linear extrapolation based on Figure 1 (projecting the line of best fit forward), which indicates that SDG1 will be attained.

Yet this encouraging picture came with warnings from the outset. There was a concern about whether the higher growth rates of the new Millennium could be maintained. Lower prices for primary commodities were a risk factor for much of Africa. The pandemic of 2020 illustrated the world's vulnerability. Based on the World Bank's mid-2020 growth projections for developing countries, Lakner et al. (2020) estimate that an extra 60 million people in 2020 are living below the Bank's $\$ 1.90$ line due to the pandemic. ${ }^{50}$

There was also a concern from early on about rising inequality. Even before the pandemic, for some observers, the fear was that the developing world's future path would be less

\footnotetext{
50 This is based on the Bank's country-specific growth projections, holding relative distribution constant. Updates found here suggest a higher count, namely 70-100 million. Sumner et al (2020) use hypothetical rates of contraction, also assuming distribution neutrality. Their "low case" of a 5\% income contraction gives an extra 80 million people living under $\$ 1.90$ a day due to the pandemic. Naturally, a higher contraction gives a higher count of the "new poor;" a $20 \%$ contraction adds 420 million to the poverty count. There is a worrying degree of indeterminacy here; this method can give any impact estimate one wants.
} 
pro-poor, possibly more like what have been seen in America. The specter of rising inequality in many (but certainly not all) developing countries was seen to threaten progress. The "60 million" calculation assumes that the "COVID-contraction" is distribution-neutral, which seems unlikely. Inequality is likely to rise within many countries given that poorer households are less able to maintain their earnings and consumption during the pandemic. As Lakner et al. (2020) point out, even a seemingly modest increase in inequality within countries could push the COVID impact on poverty up to 90 million people or more.

Critics of SDG1 also questioned the choice of the World Bank’s \$1.90 yardstick, arguing that it was too low — not ambitious enough as a goal for ending poverty — and thus it "fosters complacency" (Alston 2020, p.3). ${ }^{51}$ It can certainly be agreed that it is a frugal line, being explicitly set according to the national poverty lines found in the poorest countries. ${ }^{52}$ Higher lines are often used, including by the Bank. Critics often make the mistake of thinking that because higher lines show more poverty that implies less success against poverty. Yet it has long been known that the claim that poverty measures - the poverty rate but also the "higher-order" measures - have been falling in the world since the early 1980s is robust to the choice of the poverty line over a wide range (Chen and Ravallion, 2010; Ravallion 2020c).

The target date cannot be too far away. Setting any target date much more than (say) 20 years ahead would weaken the incentive effect on the efforts of politicians, administrators and civil society groups. It would just be too far away and myopia would no doubt set in. Nor can the target income level be too high. One is unlikely to get far in mobilizing action to eliminate poverty within any reasonable time period using (say) the U.S. official poverty line (around \$15 a day per person), which is not attained by over $90 \%$ of the people in the world. Nor is it obvious that a line more common in middle-income countries - such as $\$ 5.50$ a day, which is not reached by $45 \%$ of the world's population - would have much more motivational power. By setting a relatively frugal line, yet a close target date, the hope was that effective action could be

\footnotetext{
51 This relates to a larger debate on the Bank's poverty measures; see the compilation in Anand et al. (2010). A primary concern was that the Bank's main international line was based on national poverty lines in poor countries, which do not all use the same nutritional requirement or allowances for non-food goods. Allen (2017) provides global measures that do that. Using a nutritional requirement similar to those typical of low-income countries, Allen's method gives similar results to the Bank's, and the trends over time appear to be similar (Ravallion 2020c). Also see the discussion in Atkinson (2019).

${ }^{52}$ Ferreira et al. (2016) proposed the $\$ 1.90$ line as an update to 2011 prices of the $\$ 1.25$ line in 2005 prices set by Ravallion et al. (2009), which was used in setting SDG1.
} 
motivated, to get everyone up to that line. We can then move on to reach a higher minimum (as Lampman, 1971, had suggested with regard to the US War on Poverty).

Another perspective on the validity of the incentive argument for using a higher line in SDG1 is provided by the comparisons above of Figures 1 and 2. Anyone concerned about poverty would surely want to know how the poorest stratum is doing. Figure 2 suggests that the poorest have indeed been left behind. That points to a questionable feature of MDG1, as noted. It also raises a concern about more ambitious poverty lines. The higher poverty rate implied by a higher line that $\$ 1.90$ can be reduced by lifting those near the line out of poverty while leaving the poorer strata behind. The $40 \%$ of Sub-Saharan Africa's population living below $\$ 1.90$ a day could be safely ignored for quite a while if we used (say) $\$ 5.50$ a day as the target. One might even argue that SDG1 should have used a lower line than $\$ 1.90$. The more important point, however, is to look at how the distribution has evolved, including the poorest, who must surely have highest priority on ethical grounds.

Nor should it be forgotten that many of those who rose above $\$ 1.90$ over recent decades are still poor by the standards typical of the country they live in (Ravallion and Chen, 2019). There is a serious concern that any international poverty line with constant purchasing power has only a superficial internationalist appeal — one can argue that it should be a globally common level of welfare, which also depends on (among other things) relative income. The absolute poverty measures used in Figure 2 keep the real value of the line constant. In practice, the real value of national poverty lines tends to drift upwards as the mean rises; Ravallion and Chen (2019) estimate that the average elasticity is about 0.5 across developing countries and over time. That would halve the elasticity of poverty reduction to growth implied by Figure 3.

While granting these points, surely nobody can doubt the attraction of finally living in a world in which nobody is as poor as the $40 \%$ of the world's population that lived below $\$ 1.90$ a day 40 years ago, or as poor as the $40 \%$ of the population of Sub-Saharan Africa living below $\$ 1.90$ today. This would be undeniable progress even if it falls short of attaining other goals.

The last 3\%: Recall that the World Bank's goal is a poverty rate of 3\% by 2030, while SDG1 aims to "end poverty" by 2030 . That 3\% difference is no small matter. One possible concern is that measurement errors and uninsurable transient socks may make it virtually impossible to get the measured poverty rate based on surveys below some critical level. However, since many countries have been able to get their poverty rate below $3 \%$ over a 
sustained period, it is reasonable to assume that the relevant critical level is lower than $3 \%$.

A deeper problem is that the last $3 \%$ could well be much harder to reach even with good resources and policies. While Figure 3 is compelling that economic growth has come hand-inhand with lower poverty incidence over the longer term, we have seen that essentially the same data suggest that the poorest have benefited rather little from that growth (Figure 2). Then bringing the poorest up to $\$ 1.90$ - and thus ending poverty, though acknowledging that measurment problems may still cloud the picture - could take a lot longer even if past growth is fully restored post-pandemic.

In this respect, it is instructive to look more closely at the countries that have been relatively successful against poverty. In possibly the most successful country in this respect, Malaysia, it took 30 years to go from a poverty rate of $3 \%$ to virtually zero (Ravallion, 2020b). A slowdown for the poorest was also evident in East Asia as a whole, even prior to the pandemic. Ravallion (2020a) studied the 18 countries globally that had suceeded in getting their poverty rate below $3 \%$, while it had been over $10 \%$ at some time since the early 1980 s. For those countries, average progress in raising the floor has been close to zero once the last $3 \%$ was reached (and not statistically different from zero).

Theory and evidence also point to a number of reasons why the poorest might be left behind (Ravallion 2020a). This echoes Galbraith's (1958) distinction between "generalized poverty" (amenable to economic growth associated with rising average productivity) and other forms that are more detached from the growth process. The overall experience of even the relatively successful developing countries suggests that this is a serious concern today.

The cost of ending poverty: Lampman (1965) provided an early example of a calculation that was to become popular: the aggregate poverty gap. This imagines a set of meanstested transfers that exactly fill the poverty gaps and so bring everyone up to the desired minimum income. Subsequently, this came to be identified as the cost of ending poverty using transfers. Sachs $(2005$, p.290) used the aggregate poverty gap to see how much foreign aid would be needed to end poverty. Chandy et al. (2016) calculated that the global poverty gap was about $\$ 80$ billion dollars (using the $\$ 1.90$ line) and called on the world's billionaires to close the gap, and so end poverty. Lowrie (2017) drew on the Chandy et al. calculation to argue that "We have the resources to eliminate extreme poverty this year"; Lowrie went on to say that "...the global poverty gap is roughly what Americans spend on lottery tickets every year, and it is about half of 
what the world spends on foreign aid." The poverty gap calculation also suggests that the cost of ending poverty has been falling. The world's poverty gap per capita fell from $\$ 0.18$ in 1999 to \$0.06 in 2015 (both in 2011 PPP \$s per day). Alongside more resources for ending poverty, the "price" for doing so has fallen and is now quite low; or so it seems.

These calculations are deceptive. Incentive effects are a concern as they were with the Speenhamland scheme. When (actual or potential) recipients realize that their final income is unrelated to how much work they do, the cost of ending poverty could be much higher. ${ }^{53}$ There have also been concerns about the stigmatization of such policies (Walker 2014), and their political economy - that fine targeting can undermine its own political support (Korpi and Palme, 1998; Gelbach and Pritchett 2000). But possibly the biggest problem is more mundane: Governments do not have the information needed for doing such fine targeting well. ${ }^{54}$

Consider instead a UBI sufficient to close the gap between the floor and the poverty line. This is a more realistic policy for estimating the cost of ending poverty using transfers. It would have minimal information requirements, it is unlikely to have much effect on work incentives, and it would have broad political support. Using the estimate of the floor in Figure 2, the cost of a global UBI to eliminate $\$ 1.90$-a-day poverty would be $\$ 0.91$ per day per capita in 2015 , or $2.2 \%$ of global GDP. Unlike the poverty gap, it is not falling; in 1999 it was also \$0.91 per day.

The reader can decide if this is "high" or "low." Of course, one would also have to consider how the UBI is financed. As Ravallion (2010) shows, if financed domestically, the required marginal tax rates on incomes of the non-poor would probably be prohibitive in many developing countries. The money might be found by cutting other public spending, but the incidence of the spending cuts would need to be considered.

\section{Conclusions}

Goals are often set with the aim of motivating effort to help attain them. To do that, the chosen goal cannot be either too easy or too hard. In the context of ending poverty, the goal must be seen to be attainable, albeit with extra effort. The chosen goal will depend on many factors,

\footnotetext{
53 Taken literally, perfect targeting implies 100\% marginal tax rates on poor people; allowing for likely incentive effects, the poverty minimizing tax rate is probably closer to $50 \%$ (Kanbur et al. 1994).

${ }^{54}$ Commonly used "proxy-means tests" generate large exclusion errors-leaving many poor people without help; see Brown et al. (2018) using data for Africa.
} 
including prevailing redistributive preferences amongst those in power, the available resources, the extent and depth of poverty, and whether poor people have a political voice.

History confirms the intuition that "ending poverty" has little political traction as a nearterm goal when mass chronic poverty is seen to be the norm and poor citizens have little political influence. When those conditions no longer hold, a political goal of "ending poverty" can motivate public action to end poverty. However, while political constraints matter, they are not deterministic. Social and economic thought, and data, have often played a role. One could not talk seriously about ending poverty until it was agreed that less poverty was a good thing, and here Adam Smith was influential in overturning the prior mercantilist thinking that saw poverty as essential for wealth generation. Descriptions (both qualitative and quantitative) of the lives of poor people have also had much influence, often shaming the non-poor into supporting actions to help poor people.

Setting poverty lines is invariably contestable, not least when setting goals for poverty reduction. A high line risks falling flat in mobilizing action. Too low a line may well do nothing. MDG1 and SDG1 are anchored to a frugal global line, intended to have constant purchasing power over time and space. The time periods were also similar - about 15 years ahead, which seems reasonable for motivating effort now. The big difference was that MDG1 only aimed to halve the poverty rate, which could be done by leaving the poorest half behind. The fact that MDG1 was achieved has been taken by some observers to imply that it was hugely motivational, though some of the claims made for the power of MDG1 have clearly been exaggerated. One might equally well argue that MDG1 was not ambitious enough, given that it was attained ahead of time. More worryingly, however, is that halving the 1990 poverty rate was attained with only modest gains to the poorest.

SDG1 is clearly more ambitious and directive. It focuses attention on the poorest $10 \%$ globally, although it also highlights regional priorities; $40 \%$ of the population of Sub-Saharan Africa still live below that line. Importantly, SDG1 cannot be attained if the poorest are left behind, as we saw in the MDG1 period. Attaining SDG1 will clearly not be the "end of poverty" (as the U.N.'s rousing labelling of the goal suggests). Many of those who are no longer poor by the global $\$ 1.90$ standard will still be poor by the (defensible) standards of the country they live in. Nonetheless, getting everyone above a global line that $10 \%$ do not currently reach, and $40 \%$ did not attain 40 years ago, would be an achievement. 
The path to attaining SDG1 calls for some combination of economic growth, especially when fueled by pro-poor technical progress, and pro-poor redistribution. The political context clearly matters to the relative importance of growth versus redistribution, but so does the level of economic development. When there is a lot of poverty-such that redistribution is politically and economically challenging, if not impossible - economic growth may be all that we can hope for as a politically feasible response. There have been cases of rising poverty with economic growth, but they are rare over the longer term. The Catch-22, however, is that poverty typically makes it harder to grow an economy.

The dynamics of poverty reduction can sometimes work synergistically with the political economy to accelerate progress; the heavy lifting is done by growth, but then redistribution starts to take over. This virtuous cycle has been evident at times in the history of development, but it can come unstuck, especially when the poorest are harder to reach, and one can point to arguments and evidence as to why that might be so. It is undeniably good news that fewer people live near the floor to living standards, but it is sobering that the floor has not risen more.

SDG1 will probably not be attained with a return to "business as usual" after the COVID19 pandemic. Restoring economic growth in poor countries will almost certainly be required. There is scope for more effective redistributive policies, and even efficiency-promoting redistributions, though there are continuing challenges in assuring that these policies reach the poorest. There is also a more widespread recognition that the economic growth that has helped so much to reduce aggregate poverty measures has also come with environmental costs, including global warming. Huge challenges lie ahead in how to manage the likely tradeoffs between the "social" and "environmental" SDGs. 


\section{References}

Abel-Smith, Brian, and Peter Townsend, 1966. The Poor and the Poorest: A New Analysis of the Ministry of Labour's Family Expenditure Surveys of 1953-54 and 1960. London: Bell.

Alkire, Sabina, and James Foster, 2011. "Counting and Multidimensional Poverty Measurement," Journal of Public Economics 95(7-8): 476-487.

Allen Robert, 2009. The British Industrial Revolution in Global Perspective. Cambridge: Cambridge University Press. , 2017. “Absolute Poverty: When Necessity Displaces Desire,” American Economic Review 107(12): 3690-3721.

Alston, Philip, 2020. “The Parlous State of Poverty Eradication.” Report of the Special Rapporteur on extreme poverty and human rights, United Nations Human Rights Council, New York.

Anand, Sudhir, Paul Segal, and Joseph Stiglitz (eds), 2010. Debates on the Measurement of Poverty. Oxford: Oxford University Press.

Anderson, Martin, 1978. Welfare. The Political Economy of Welfare Reform in the United States. Palo Alto: Hoover Institution, Stanford University.

Atkinson, Anthony, 1987. “On the Measurement of Poverty,” Econometrica 55: 749-764. , 1995, Public Economics in Action: The Basic Income/Flat Tax Proposal. Oxford: Oxford University Press. , 1998, Poverty in Europe. Oxford: Blackwell Press. , 2019. Measuring Poverty around the World. Princeton: Princeton University Press.

Bardhan, Pranab, and T N Srinivasan (eds), 1974. Poverty and Income Distribution in India. New Delhi: Statistical Publishing House.

Bateman, Bradley, 2001. "Make a Righteous Number: Social Surveys, the Men and Religion Forward Movement, and Quantification in American Economics," History of Political Economy 33: 57-85.

Baumol, William, 1983. "Marx and the Iron Law of Wages," American Economic Review, Papers and Proceedings, 73(2): 303-308.

Beaudoin, Steven, 2006. Poverty in World History. New York: Routledge. 
Bentham, Jeremy, 1843. "Tracts on Poor Laws and Pauper Management," in The Works of Jeremy Bentham, Volume 8. Edinburgh: William Tait.

Besley, Timothy, Stephen Coate and Timothy Guinnane, 2004. "Incentives, Information and Welfare: England's New Poor Law and the Workhouse Test," in T.W. Guinnane, W.A. Sundstrom and W. Whatley (eds) History Matters. Essays on Economic Growth, Technology and Demographic Change. Stanford: Stanford University Press.

Beveridge, William, 1942. Social Insurance and Allied Services. London: His Majesty's Stationary Office.

Blank, Rebecca M., 2008. "How to Improve Poverty Measurement in the United States," Journal of Policy Analysis and Management 27(2): 233-254.

Blaug, Mark, 1963. "The Myth of the Old Poor Law and the Making of the New," Journal of Economic History 23(2): 151-184.

Block, Fred, and Margaret Somers, 2003. "In the Shadow of Speenhamland: Social Policy and the Old Poor Law," Politics \& Society 31: 283-323

Bourguignon, Francois, and Christian Morrisson, 2002. "Inequality among World Citizens: 1820-1992," American Economic Review 92(4): 727-744.

Bowley, Arthur L., 1915, The Nature and Purpose of the Measurement of Social Phenomena. London: P.S. King and Sons.

Boyer, George, 1990. An Economic History of the English Poor Law 1750-1850. Cambridge: Cambridge University Press.

Bregman, Rutger, 2017. Utopia for Realists. How we can Build an Ideal World. New York: Little Brown and Co.

Bremner, Robert, 1956. From the Depths: The Discovery of Poverty in the United States. New Haven: Yale University Press.

Brown, Caitlin, Martin Ravallion and Dominique van de Walle, 2018, “A Poor Means Test? Econometric Targeting in Africa," Journal of Development Economics 134: 109-124. and , 2019. "Most of Africa's Nutritionally-Deprived Women and Children are Not Found in Poor Households," Review of Economics and Statistics 101(4): 631-644.

Chandy, Lawrence, Lorenz Noe, and Christine Zhang, 2016. "The Global Poverty Gap is Falling. Billionaires could Help Close it." Brookings Institution, Washington DC. 
Chen, Shaohua, and Martin Ravallion, 2010. "The Developing World is Poorer than we Thought, but no less Successful in the Fight Against Poverty," Quarterly Journal of Economics 125(4): 1577-1625.

Chen Shaohua and Martin Ravallion, 2012. "More Relatively-Poor People in a Less AbsolutelyPoor World," Policy Research Working Paper 6114, World Bank.

Chenery, Hollis, 1977. Forward to David Morawetz, Twenty-Five Years of Economic Development. Washington DC: World Bank.

Chenery, Hollis, Montek S. Ahluwalia, Clive Bell, John Duloy and Richard Jolly, 1974. Redistribution with Growth. Oxford: Oxford University Press.

Citro, Constance, and Robert Michael, 1995. (eds.) Measuring Poverty: A New Approach. Washington, DC: National Academy Press.

Clark, Gregory, and Marianne Page, 2019. "Welfare Reform, 1834: Did the New Poor Law in England Produce Significant Economic Gains?” Cliometrica 13:221-244.

Coats, A.W. 1992. On the History of Economic Thought. London: Routledge.

Cornia, Giovanni, Richard Jolly and Francis Stewart (eds.), 1987. Adjustment with a Human Face: Protecting the Vulnerable and Promoting Growth. Oxford: Oxford University Press.

Crafts, N.F.R. and Terence Mills, 1994. "Trends in Real Wages in Britain, 1750-1913," Explorations in Economic History 31(2): 176-194.

Dandekar, V.M., and N. Rath, 1971. Poverty in India. Pune: Indian School of Political Economy. Datt, Gaurav, and Martin Ravallion, 1998. "Farm Productivity and Rural Poverty in India," Journal of Development Studies 34(4): 62-85.

Datt, Gaurav, Martin Ravallion and Rinku Murgai, 2020. "Poverty and Growth in India over Six Decades", American Journal of Agricultural Economics, forthcoming.

Davies, David. 1776. The Case of the Labourers in Husbandry Stated and Considered, in Three Parts. Dublin: P. Byrne.

Dawson, Miles Menander, 1915. The Ethics of Confucius, at sacred-texts.com.

Deaton, Angus, 2013. The Great Escape: Health, Wealth, and the Origins of Inequality. Princeton NJ: Princeton University Press.

De Vreyer, Philippe, and Sylvie Lambert, 2020, “Inequality, poverty and the intra-household allocation of consumption in Senegal," World Bank Economic Review, in press. 
Dollar, David, and Aart Kraay, 2002. "Growth is Good for the Poor," Journal of Economic Growth, 7(3): 195-225.

Drèze, Jean, and Amartya Sen, 1989. Hunger and Public Action. Oxford: Oxford University Press.

Dutta, Puja, Rinku Murgai, Martin Ravallion and Dominique van de Walle, 2014, Right-toWork? Assessing India's Employment Guarantee Scheme in Bihar. World Bank. Easterly, William, 2006. The White Man's Burden: Why the West's Efforts to Aid the Rest Have Done So Much Ill and So Little Good. Oxford: Oxford University Press.

Eden, Frederick Morton, 1797. The State of the Poor. London: J. Davis.

Engels, Friedrich, 1845. The Condition of the Working Class in England. Oxford: Oxford University Press, 1993 edition.

Ferreira Francisco, Shaohua Chen, A. Dabalen, Y. Dikhanov, N. Hamadeh, D. Joliffe, A. Narayan, E. Prydz, A. Revenga, P. Sangraula, U. Serajuddin, N. Yoshida, 2016. “A Global Count of the Extreme Poor in 2012: Data Issues, Methodology and Initial Results," Journal of Economic Inequality 14: 141-172.

Ferreira, Francisco, and Martin Ravallion, 2009, "Poverty and Inequality: The Global Context," in The Oxford Handbook of Economic Inequality, edited by Wiemer Salverda, Brian Nolan and Tim Smeeding, Oxford: Oxford University Press.

Fleischacker, Samuel, 2004. A Short History of Distributive Justice. Cambridge MA: Harvard University Press.

Foster, James, Joel Greer, and Erik Thorbecke, 1984. "A Class of Decomposable Poverty Measures," Econometrica 52: 761-765.

Friedman, Milton, 1962. Capital and Freedom. Chicago, University of Chicago Press.

Fuchs, Victor, 1967. “Redefining Poverty and Redistributing Income," The Public Interest 8: 8895.

Galbraith, John Kenneth, 1958. The Affluent Society. Boston: Mariner Books.

Gans, Herbert, 1995. The War Against the Poor, New York: Basic Books.

Gazeley, Ian and Nicola Verdon, 2014. "The First Poverty Line? Davies and Eden's

Investigation of Rural Poverty in Late 18th-century England." Explorations in Economic History 51: 94-108.

Gelbach, Jonah, and Lant Pritchett, 2000. "Indicator Targeting in a Political Economy: Leakier 
can be Better." Journal of Policy Reform 4: 113-45.

Genicot, Garance, and Debraj Ray, 2020. "Aspirations and Economic Behavior," Annual Review of Economics 12: 715-746.

Glaper, Jeffry, 1970. “The Speenhamland Scales: Political Social, or Economic Disaster?” Social Service Review 44(1): 54-62.

Guardian, 2005. "Poverty campaign banned from TV, radio ads," The Guardian September 12.

Haddad, Lawrence, and Ravi Kanbur, 1990. "How Serious is the Neglect of Intra-Household Inequality?," Economic Journal 100: 866-881.

Harrington, Michael, 1962. The Other America: Poverty in the United States. New York: Macmillan.

Haveman, Robert, Rebecca Blank, Robert Moffitt, Timothy Smeeding, and Geoffrey Wallace, 2015. "The War on Poverty: Measurement, Trends, and Policy," Journal of Policy Analysis and Management, 34(3): 593-638.

Himmelfarb, Gertrude, 1984. The Idea of Poverty: England in the Early Industrial Age. London: Faber and Faber.

Hollander, Jacob, 1914. The Abolition of Poverty. Boston: Houghton Mifflin.

Hulme, David, 2009. "The Millennium Development Goals (MDGs): A Short History of the World's Biggest Promise," BWPI Working Paper 100, Brooks Institute, University of Manchester.

Hunter, Marjorie, 1964. "Myrdal Says Special Treatment for Negros would Stir Hatred," New York Times January 24.

Hunter, Robert, 1904. Poverty, London: MacMillan Company.

International Labour Organization (ILO), 1976. Employment, Growth and Basic Needs: A OneWorld Problem. Geneva: International Labour Organization.

Johnson, Lyndon B., 1964. Economic Report of the President. United States Government Printing Office.

Jolliffe, Dean, Juan Margitic and Martin Ravallion, 2019. "Food Stamps and America's Poorest," NBER Working Paper 26025.

Jütte, Robert, 1994. Poverty and Deviance in Early Modern Europe. Cambridge: Cambridge University Press 
Kanbur, Ravi, Michael Keen and Matti Tuomala, 1994. "Labor Supply and Targeting in Poverty Alleviation Programs," World Bank Economic Review 8(2): 191-211.

Kant, Immanuel, 1785. Fundamental Principles of the Metaphysic of Morals (Thomas Kingsmill Abbott. ed. 10 edition). Project Gutenberg.

Katz, Michael, 1987. The Undeserving Poor: From the War on Poverty to the War on Welfare. New York: Pantheon Books. , 1996. In the Shadow of the Poorhouse. A Social History of Welfare in America. New York: Basic Books.

Kautilya, undated. Arthashastra, R. Shamasastry's translation. Bangalore: Government Press. Keynes, John Maynard, 1930. “Economic Possibilities for our Grandchildren.” In John Maynard Keynes, Essays in Persuasion, New York: W.W.Norton \& Co.. 1936. The General Theory of Employment, Interest and Money. London: Macmillan Press.

Korpi, Walter and Joakim Palme, 1998. "The Paradox of Redistribution and Strategies of Equality: Welfare State Institutions, Inequality, and Poverty in the Western Countries," American Sociological Review 63(5): 661-687.

Lakner, Christoph, Daniel Gerszon Mahler, Mario Negre, Espen Beer Prydz, 2020, "How Much Does Reducing Inequality Matter for Global Poverty?” Global Poverty Technical Note 13, World Bank.

Lampman, Robert, 1959. "The Low Income Population and Economic Growth in the United States," Joint Economic Committee of Congress, Washington DC. , 1965. "Approaches to the Reduction of Poverty," American Economic Review 55(1/2): 521-529. , 1971. Ends and Means of Reducing Income Poverty. Chicago: Markham Publishing.

Landauer, Carl, 1959. European Socialism: A History of Ideas and Movements from the Industrial Revolution to Hitler's Seizure of Power. Berkeley: University of California Press.

Lindert, Peter H., 2004. Growing Public: Volume 1, The Story: Social Spending and Economic Growth since the Eighteenth Century. Cambridge: Cambridge University Press. 
Lipton, Michael, and Richard Longhurst, 1989. New Seeds and Poor People. Baltimore: Johns Hopkins University Press.

Lloyd, Amy, 2007. "Education, Literacy and the Reading Public.” British Library Newspapers. Detroit: Gale.

Lowrie, Annie, 2017. “The Future of Not Working,” New York Times, February 23.

Marshall, Alfred, 1890. Principles of Economics ( th $^{\text {th }}$ edition, 1920), London: Macmillan.

Marx, Karl, 1867. Capital Volume 1. Moscow: Progress Publishers, 1966.

Milanovic, Branko, 2016. Global Inequality. A New Approach for the Age of Globalization. Cambridge, Mass.: Belknap Press.

Moffitt, Robert, 2015. "The Deserving Poor, the Family, and the U.S. Welfare System," Demography 52: 729-749.

Nehru, Jawaharlal, 1947. "Tryst with Destiny," Speech to the Indian Constituent Assembly.

O’Connor, Alice, 2001. Poverty Knowledge. Social Science, Social Policy, and the Poor in Twentieth-Century U.S. History, Princeton: Princeton University Press.

Orshansky, Mollie, 1965. "Counting the Poor: Another Look at the Poverty Profile," Social Security Bulletin 28: 3-29.

Paine, Thomas, 1791. The Rights of Man: Being a Response to Mr Burke's Attack on the French Revolution, London: J.S. Jordan. , 1797. Agrarian Justice, 2004 edition published with Common Sense by Penguin.

Petty, Sir William, 1662. A Treatise of Taxes and Contributions. Reprinted in The Economic Writings of Sir William Petty, Vol. I, edited by C. H. Hull. Cambridge: University Press, 1899.

Piketty, Thomas and Emmanuel Saez, 2014. "Inequality in the Long Run,” Science 344: 838843.

Piven, Frances Fox, and Richard Cloward, 1979. Poor People's Movements. Why they Succeed and how they Fail. New York: Vintage Books.

Polanyi, Karl, 1957. The Great Transformation: The Political and Economic Origins of Our Time. Boston: Beacon Press.

Pressman, Steven, 1991. "Keynes and Antipoverty Policy,” Review of Social Economy 49(3): 365-382. 
Ravallion, Martin, 1997. "Can High Inequality Developing Countries Escape Absolute Poverty?" Economics Letters, 56, 51-57.

, 2001. "Growth, Inequality and Poverty: Looking Beyond Averages." World Development 29(11): 1803-1815. ,2005, "Inequality is Bad for the Poor," Policy Research Working Paper WPS3677, World Bank (Also published in J. Micklewright and S. Jenkins (eds.), Inequality and Poverty Re-Examined. Oxford: Oxford University Press. , 2010. “Do Poorer Countries Have Less Capacity for Redistribution?” Journal of Globalization and Development 1(2): 1-29. , 2012. "Why Don't we See Poverty Convergence?” American Economic Review, 102(1): 504-523. , 2013. "How Long Will It Take to Lift One Billion People Out of Poverty?" World Bank Research Observer 28 (2): 139-158. , 2015. "The Idea of Antipoverty Policy," in A.B. Atkinson and F. Bourguignon (eds) Handbook of Income Distribution Volume 2, Amsterdam: North Holland. ,2016a. Economics of Poverty: History, Measurement and Policy. New York: Oxford University Press. , 2016b. “Are the World's Poorest Being Left Behind?" Journal of Economic Growth 21(2): 139-164. , 2020a. "SDG1: The Last Three Percent" Working Paper, Center for Global Development, Washington DC. , 2020b. "Ethnic Inequality and Poverty in Malaysia since May 1969. Part 2: Poverty," World Development, forthcoming. , 2020c. "Measuring Global Poverty," Annual Review of Economics Vol. 20. , 2020d. "What Might Explain Today's Conflicting Narratives on Global Inequality?" in Inequality in the Developing World, edited by C. Gradin, M. Leibbrandt, and F. Tarp. Oxford: Oxford University Press.

Ravallion, Martin, and Shaohua Chen, 2015. "Benefit Incidence with Incentive Effects, Measurement Errors and Latent Heterogeneity: A Case Study for China," Journal of Public Economics 128: 124-132. 

, and , 2019. "Global Poverty Measurement when Relative Income Matters," Journal of Public Economics 177: 1-13.

Ravallion Martin, Shaohua Chen, and Prem Sangraula, 2009. "Dollar a Day Revisited," World Bank Economic Review 23(2):163-184.

Ravallion, Martin, Gaurav Datt, and Dominique van de Walle, 1991. "Quantifying Absolute Poverty in the Developing World," Review of Income and Wealth 37: 345-361.

Rawls, John, 1971. A Theory of Justice, Cambridge MA: Harvard University Press.

Ricardo, David, 1817, Principles of Political Economy and Taxation. London: Everyman Edition, 1911.

Roosevelt, Franklin D., 1937. "Second Inaugural Address."

Rothschild, Emma, 1995. "Social Security and Laissez Faire in Eighteenth-Century Political Economy" Population and Development Review 21(4): 711-744,

Sachs, Jeffrey, 2005. The End of Poverty: Economic Possibilities for Our Time. New York: Penguin Books.

Saith, Ashwani, 2006. "From Universal Values to Millennium Development Goals: Lost in Translation," Development and Change 37(6): 1167-1199.

Sandmo, Agnar, 2015. "The Principal Problem in Political Economy: Income Distribution in the History of Economic Thought," in Handbook of Income Distribution, Volume 2, edited by Anthony B. Atkinson and Francois Bourguignon, Amsterdam: Elsevier Science.

Scheve, Kenneth, and David Stasavage, 2016. Taxing the Rich: A History of Fiscal Fairness in the United States and Europe. Princeton University Press.

Sen, Amartya, 1976. "Poverty: An Ordinal Approach to Measurement," Econometrica 46: 437446.

, 1985. Commodities and Capabilities. Amsterdam: North-Holland. , 1999. Development as Freedom. New York: Alfred Knopf.

Smith, Adam, 1776. An Inquiry into the Nature and Causes of the Wealth of Nations. Electronic Classic Edition, Pennsylvania State University.

Solar, Peter M., 1995. "Poor Relief and English Economic Development before the Industrial Revolution," Economic History Review 48: 1-22.

Stedman Jones, Gareth, 2005. An End to Poverty?: A Historical Debate. New York: Columbia University Press. 
Steensland, Brian, 2008. The Failed Welfare Revolution: America's Struggle over Guaranteed Income Policy. Princeton: Princeton University Press.

Sumner, Andy, Chris Hoy and Eduardo Ortiz-Juarez, 2020. "Estimates of the Impact of COVID19 on Global Poverty," WIDER Working Paper 2020/43, UNU-WIDER.

Taylor, Claire. 2017. Poverty, Wealth and Well-Being. Experiencing Penia in Democratic Athens. Oxford: Oxford University Press.

Thorner, Daniel, 1967. "Social and Economic Studies of Dr Mann," Economic and Political Weekly 2(13): 612-645.

Trattner, Walter I., 1999. From Poor Law to Welfare State. New York: The Free Press.

UNICEF, 1961. “The 1960: Decade of Development," UNICEF.

Vecchi, Giovanni, 2017. Measuring Wellbeing. A History of Italian Living Standards. Oxford: Oxford University Press.

Walker, Robert, 2014. The Shame of Poverty. Oxford: Oxford University Press.

Watts, Harold, 1968. “An Economic Definition of Poverty," in Daniel P. Moynihan (ed.), On Understanding Poverty, New York, Basic Books. , 1986. "Have our measures of poverty become poorer?" Focus 9(2): 18-23.

Webb, Robert K., 1974. Modern England from the 18th Century to the Present. New York: Dodd, Mead and Company.

World Bank, 1980. World Development Report: Poverty and Human Development, New York: Oxford University Press. , 1986. Poverty and Hunger. Issues and Options for Food Security in Developing Countries. World Bank. , 1990. World Development Report: Poverty. New York: Oxford University Press. , 2006. World Development Report: Equity and Development. New York: Oxford University Press. , 2015. A Measured Approach to Ending Poverty and Boosting Shared Prosperity. Washington DC: World Bank.

Young, Allyn, 1917, "Do the Statistics of the Concentration of Wealth in the United States Mean what they are Commonly Assumed to Mean?" American Statistical Association New Series 117: 471-84. 
Zheng, Buhong, 1993. "Axiomatic Characterization of the Watts Index," Economics Letters 42: 81-86. 